\title{
Postglacial alluvial fan dynamics in the Cordillera Oriental, Peru, and palaeoclimatic implications
}

\author{
Kevin Ratnayaka $^{\mathrm{a}}$, Ralf Hetzel ${ }^{\mathrm{a}, *}$, Jens Hornung ${ }^{\mathrm{b}}$, Andrea Hampel ${ }^{\mathrm{c}}$, Matthias Hinderer ${ }^{\mathrm{b}}$, Manfred Frechen ${ }^{\mathrm{d}}$ \\ ${ }^{a}$ Institut für Geologie und Paläontologie, Westfälische Wilhelms-Universität Münster, Corrensstraße 24, 48149 Münster, Germany \\ ${ }^{\mathrm{b}}$ Technische Universität Darmstadt, Institut für Angewandte Geowissenschaften, Schnittspahnstraße 9, 64287 Darmstadt, Germany \\ ${ }^{\mathrm{c}}$ Institut für Geologie, Leibniz Universität Hannover, Callinstraße 30, 30167 Hannover, Germany \\ ${ }^{\mathrm{d}}$ Leibniz Institute for Applied Geophysics, Geochronology \& Isotope Hydrology, Stilleweg 2, 30655 Hannover, Germany \\ (ReCEIVED December 11, 2017; AcCEPTED August 20, 2018)
}

\begin{abstract}
Alluvial fans record climate-driven erosion and sediment-transport processes and allow reconstructing past environmental conditions. Here we investigate the sedimentation history of two alluvial fans located in formerly glaciated valleys of the Cordillera Oriental, Peru. ${ }^{10} \mathrm{Be}$ exposure ages from the fan surfaces and radiocarbon ages from the fan interiors constrain the final stages of fan formation. The ${ }^{10} \mathrm{Be}$ and ${ }^{14} \mathrm{C}$ ages cluster mainly between $13.3-9.3 \mathrm{ka}$ and $11,500-9700 \mathrm{cal} \mathrm{yr} \mathrm{BP}$, respectively. Our age data set indicates that-after deglaciation-large amounts of fan sediment were deposited until $\sim 10 \mathrm{ka}$, when sedimentation rates declined rather abruptly. This pattern is supported by ${ }^{10} \mathrm{Be}$ erosion rates for the fan catchments, because under the assumption of constant erosion the time needed to erode the material stored in the fans significantly exceeds their age. Correlating our ages with regional climate records indicates that precipitation exerts the primary control on fan sedimentation. Two periods with elevated lake levels and increased precipitation between 18 and $14.5 \mathrm{ka}$ and from 13 to $11.5 \mathrm{ka}$ resulted in rapid deposition of large fan lobes. Subsequently, lower precipitation rates decreased erosion in the catchments and sediment delivery to the fans, which have remained largely inactive since $\sim 9.5 \mathrm{ka}$.
\end{abstract}

Keywords: Alluvial fan; Sedimentation rate; Climate history; ${ }^{10} \mathrm{Be}$ exposure dating; ${ }^{14} \mathrm{C}$ dating; Peru; Andes

\section{INTRODUCTION}

Alluvial fans are dynamic sediment bodies, whose morphology and stratigraphy reflect the climatic and tectonic conditions during their formation (Bull, 1977; Blair and McPherson, 1994; Dorsey et al., 1997; Harvey et al., 1999). Among the geomorphological parameters that may change during the evolution of an individual fan are its radial length, the slope of the fan surface and the source area, and the location of the active fan toe (Oguchi and Ohmori, 1994; Humphrey and Heller, 1995; Densmore et al., 2007). Alluvial fans are often segmented into different depositional lobes that may differ in age and in the environmental conditions under which they were deposited (Bull, 1964; Blair and McPherson, 1998). Parameters that control the sedimentologic inventory of a fan include the lithology in the source area, the grain size, and the sediment transport and storage regime (e.g., Bull 1962; Dade and Friend, 1998; Paola et al., 1992;

*Corresponding author at: Institut für Geologie und Paläontologie, Westfälische Wilhelms-Universität Münster, Corrensstraße 24, 48149 Münster, Germany. E-mail address: rahetzel@uni-muenster.de (R. Hetzel).
Blair, 1999). The strong dependence of the fan characteristics on environmental boundary conditions makes alluvial fans unique recorders of climatic and tectonic changes (Bull, 1977; Blair and McPherson, 1994; Dorsey et al., 1997; Harvey et al., 1999).

To quantify the relationships between fan morphology and the parameters controlling fan evolution, Densmore et al. (2007) applied a model of an individual coupled catchmentfan system and varied, among other parameters, fault slip and precipitation rates. Their results showed that in periods with higher precipitation rates, the sediment yield from the source area was high and the fan lobe deposited during this period had a larger spatial extent but a lower slope. In contrast, a decrease in precipitation and hence sediment yield from the catchment will lead to deposition of smaller fan lobes with higher slope angles (Densmore et al., 2007). Despite the firstorder control of environmental conditions on fan formation, the actual shape and architecture of a natural fan may be affected by autogenic processes that determine, for example, the distribution and activity of channels and lobes (e.g., Ventra and Nichols, 2014). 
Linking fan stratigraphy and changes in fan morphology to tectonic events or regional climate variations requires age constraints for the fan surface and interior. Such age data are particularly important against the background that often fan formation cannot be unequivocally correlated with a climatic event because fan aggradation may, in principle, occur during dry and wet periods as well as during wet-dry and dry-wet transitions (e.g., Harvey et al., 2005; Dorn, 2009; Meinsen et al., 2014). Depositional units in fan interiors have been dated using ${ }^{14} \mathrm{C}$ or luminescence dating (Roskosch et al., 2012; Chiverrell and Jakob, 2013; Lang, 2013; Meinsen et al., 2014; Cable et al., 2018). Age constraints for fan surfaces are generally more difficult to obtain as their preservation is limited by the shifts of the active channels, which may lead to erosion or burial of older fan surfaces. Such buried older fan surfaces may be detectable by ground penetrating radar (Hornung et al., 2010; Franke et al., 2014). In arid regions, relative ages for the different parts of a fan surface may be derived from the degree of desert varnish development (Bull, 1991) or differences in the surface roughness (Regmi et al., 2014). Numerical ages of fan surfaces may be obtained, for example, from cosmogenic nuclide exposure dating of debris flow boulders (e.g., Dühnforth et al., 2007; Ivy-Ochs et al., 2013). This method was successfully applied to alluvial fans in semiarid or arid regions, including the Owens Valley and Death Valley in California (Dühnforth et al., 2007, 2017) and the Atacama Desert (Cesta and Ward, 2016). Fans in humid regions were studied, for example, with respect to their slopes (e.g., Saito and Oguchi, 2005), but only few studies determined absolute fan surface ages (e.g., Bellier et al., 1999; Jennings et al., 2003) or combined exposure ages with fan volume estimates (Schürch et al., 2016).

When constraints on both fan volume and age are available, this information can be used to quantify changes in sedimentation (Hornung et al., 2010) and erosion rates, which is usually only possible from marine or lake records (e.g., for tropical Andean lakes: Mourguiart et al., 1998; Rodbell et al., 2008). The temporal evolution of sedimentation and erosion rates derived from alluvial fans can ultimately be correlated with the regional climate history to investigate, for example, the relationships between variations in precipitation and sedimentation rates in natural fan systems. In formerly glaciated regions, paraglacial processes (i.e., fan formation in response to high sediment availability and slope failure during deglaciation) may also play a significant role (Church and Ryder, 1972; Hinderer, 2001).

Here we present a new data set comprising ${ }^{10} \mathrm{Be}$ exposure ages from boulders on fan surfaces, catchment-wide ${ }^{10} \mathrm{Be}$ erosion rates, and ${ }^{14} \mathrm{C}$ ages from the fan interior for two alluvial fans in the Cordillera Oriental, Peru. Our motivation to carry out this study is a lack of data on alluvial fan evolution in this region, the good preservation of the fans, the presence of datable quartz-rich boulders on the fan surfaces, and the opportunity to correlate the fan deposition history with a well-constrained regional climate record. Fans located at lower elevations in this region are less well preserved because of higher rainfall, more vegetation, and agricultural land use. Furthermore, the studied fans are located in valleys that have been cleaned out by glaciers during the last glacial maximum (LGM), which allows an estimation of the postLGM sediment volume. Finally, major lakes and palaeolakes in this part of the Andes, whose late Pleistocene-Holocene lake-level variations are well documented (Lake Titicaca and Palaeolake Tauca), offer the opportunity to correlate our results with the regional climate record. Our data show that the two studied fans are postglacial in age and that sediment deposition was largely completed by $\sim 10 \mathrm{ka}$. By comparing our results for the fan sedimentation history with regional climate records from the tropical Andes, we infer the main controls on alluvial fan and catchment dynamics.

\section{GEOMORPHOLOGICAL AND GEOLOGIC SETTING OF THE STUDY AREA}

Our study area is located in the Peruvian segment of the Andean mountain chain, approximately $300 \mathrm{~km}$ northwest of Lake Titicaca and $80 \mathrm{~km}$ east of the town of Cusco (Fig. 1). There, we studied two alluvial fans (hereafter called Ampatune and Mallma fans), which are situated at the northern margin of the Ocongate basin (Fig. 2a) at altitudes of $~ 4300$ and $\sim 4150 \mathrm{~m}$ above sea level, respectively (Fig. $2 \mathrm{~b}$ ). The study area receives an annual precipitation of about $800 \mathrm{~mm}$ and has a mean annual temperature of $6^{\circ} \mathrm{C}$ (Servicio Nacional de Meteorología e Hidrología del Perú, 2017). Because of these climate conditions and the high altitude, the vegetation on the two studied fans is limited to grasses and mosses. Today, two glaciated areas still exist in the region, one

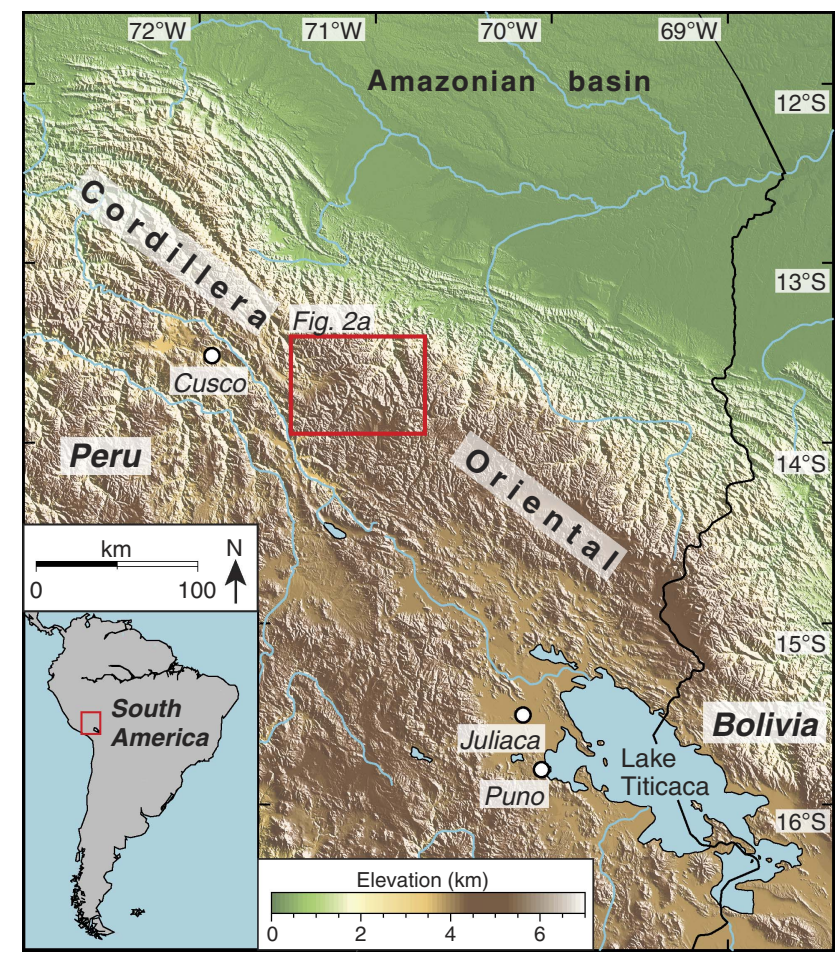

Figure 1. Topographic map of the Cordillera Oriental, Peru. Red box outlines the area of the satellite image shown in Figure 2a. 

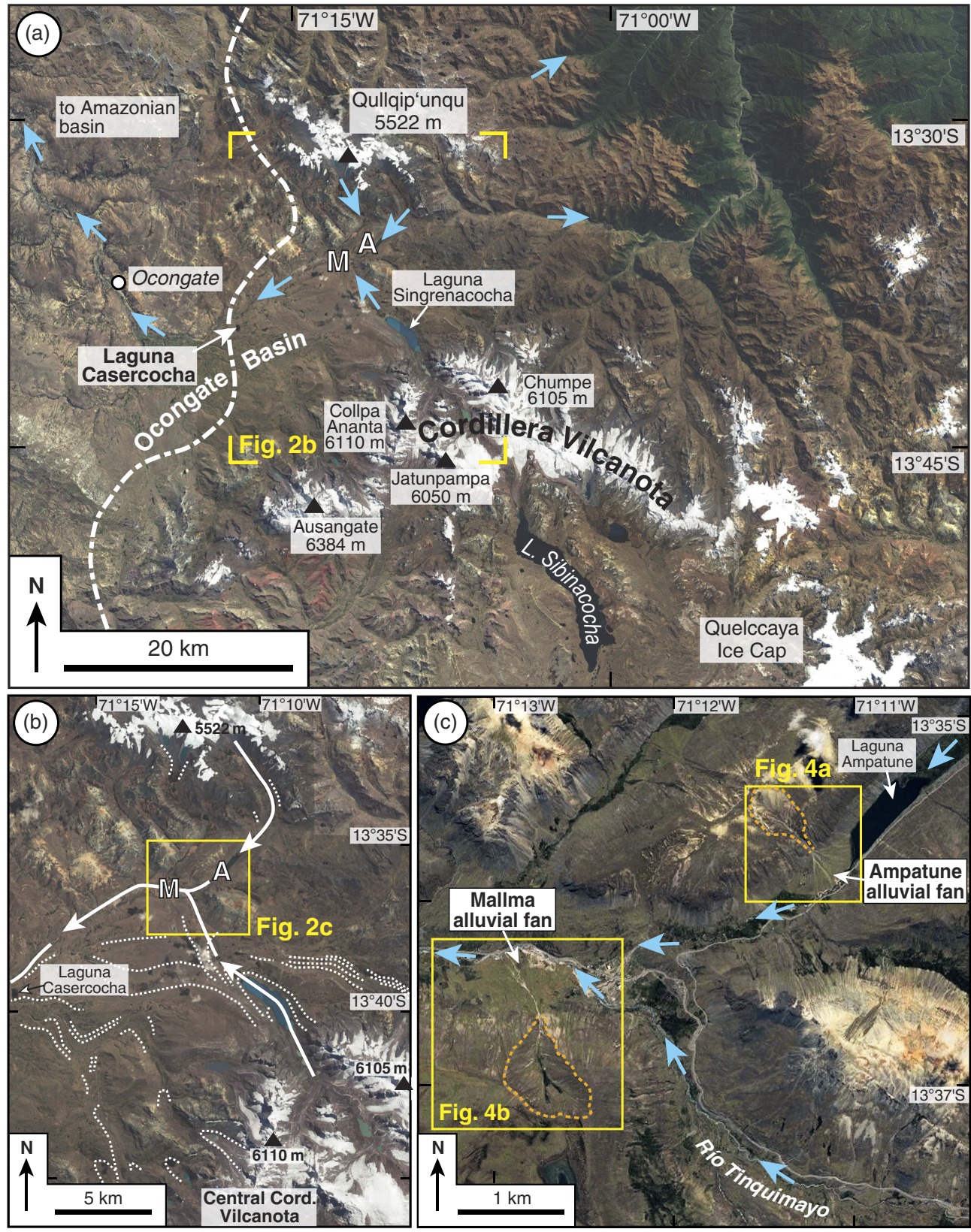

Figure 2. Satellite images of the study area and adjacent regions. (a) Cordillera Vilcanota and surrounding regions with the locations of the studied Ampatune (A) and Mallma (M) alluvial fans. Dashed white line indicates western margin of the last glacial maximum (LGM) ice extent from Ehlers et al. (2011). Blue arrows indicate flow directions of selected rivers. Corners of yellow box indicate area shown in panel (b). (b) Region between the central Cordillera Vilcanota and the Qullqip'unqu mountains with formerly glaciated valleys and the Ampatune (A) and Mallma (M) fans. Spatial distribution of moraines (dotted white lines) is based on the 1:100,000 scale geologic map of Audebaud and Vargas (1998); the maps shown in Goodman et al. (2001), Mark et al. (2002), and La Frenierre et al. (2011); and our own field observations. White arrows indicate flow directions of LGM glaciers in those valleys where the Mallma and Ampatune fans have formed after the LGM. Yellow box indicates area shown in panel (c). (c) The study area with the Ampatune and Mallma alluvial fans. Dashed orange lines mark the boundaries of the respective Ampatune and Mallma catchments. Blue arrows indicate flow directions of rivers in the valleys with the studied fans (see also Fig. 3a). Yellow boxes outline the areas with the two fans shown in Figure 4.

surrounding the Qullqip'unqu mountain $(5522 \mathrm{~m})$ and the other in the Cordillera Vilcanota, which includes the Quelccaya Ice Cap (Fig. 2a).

The Ampatune alluvial fan has a surface area of $\sim 0.25 \mathrm{~km}^{2}$ and is located downstream of the Laguna Ampatune (Figs. 2c, 3a). The fan has dammed the river, which flows from the Qullqip'unqu mountains through the lake and along the southeastern margin of the Ampatune fan before it confluences with the Río Tinquimayo (Figs. 2c, 3a). Note that the position of the Ampatune fan downstream of the Laguna Ampatune implies that the lake does not act as local base level for the fan. Where the river cuts the southeastern margin of the Ampatune fan, it has created cliffs exposing the internal fan architecture (see "Results"). 

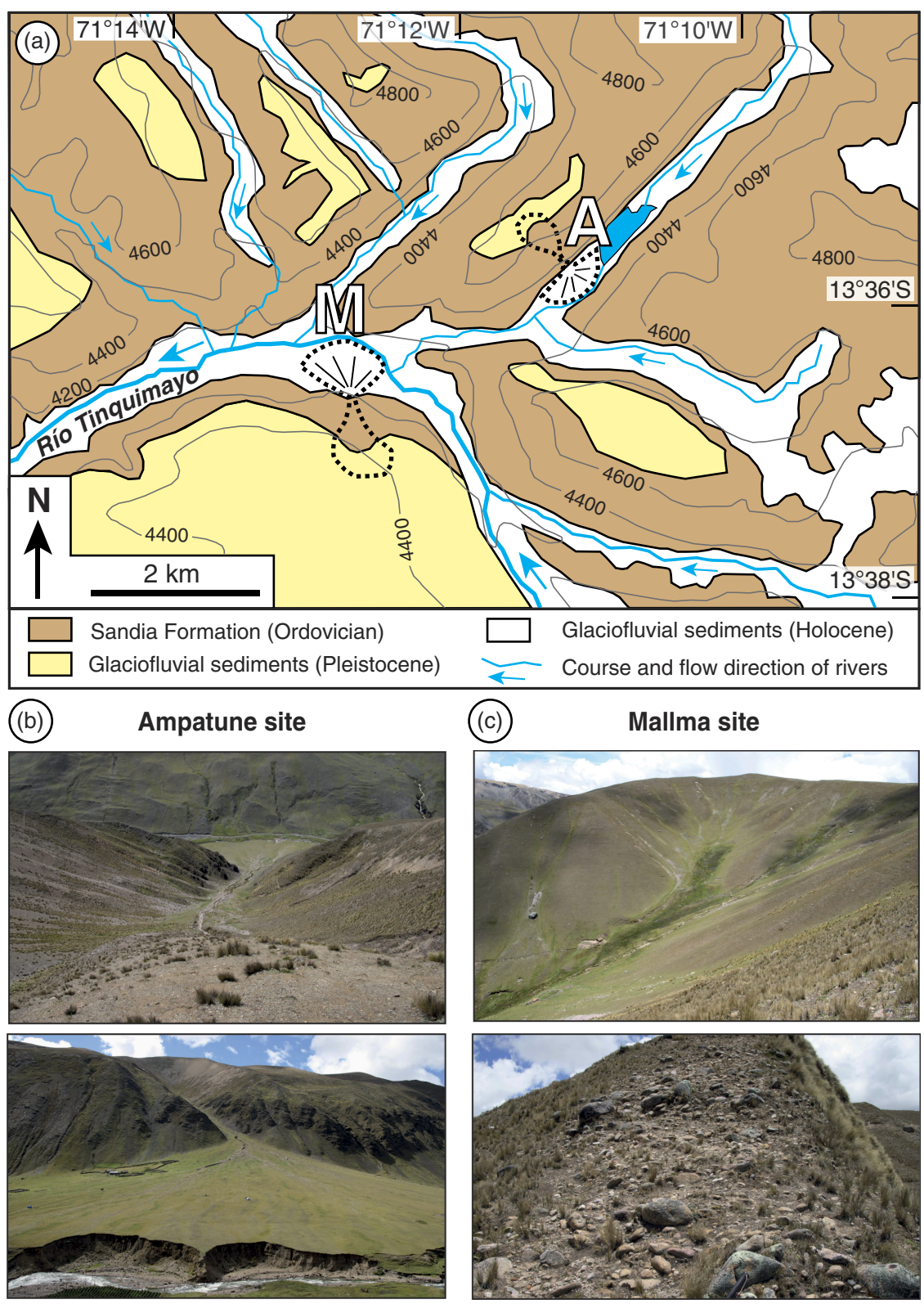

Figure 3. (a) Geologic map (with topographic contour lines in metres) of the study area showing the distribution of the Palaeozoic bedrock (Sandia Formation) and Pleistocene glaciofluvial sediments above the bedrock (map is based on Audebaud and Vargas (1998), Sanchez and Zapata (2002), and own field observations). Dashed black lines outline the Ampatune and Mallma catchment-fan systems. (b) Field photographs of the Ampatune catchment and the related fan. Note the easily erodible, red-brown sediments above the dark bedrock. (c) Overview of the Mallma catchment and outcrop with Pleistocene glaciofluvial sediments in the upper part of this catchment. The steep slope on the right indicates that the Pleistocene sediments are much more resistant to erosion than those in the Ampatune catchment.

The Mallma alluvial fan covers an area of $\sim 0.43 \mathrm{~km}^{2}$. Along the northern fan margin, the Río Tinquimayo has incised the fan and formed cliffs (Figs. 2c, 3a). Río Tinquimayo originates in the central Cordillera Vilcanota. After its confluence with the stream from the Ampatune valley, Río Tinquimayo flows to the west, past the Mallma fan (Fig. 2c). About $10 \mathrm{~km}$ west of the Mallma fan, the river passes a kettle lake called Laguna Casercocha (Fig. 2a). Note that the river does not flow through the Laguna Casercocha because the latter is situated south of the river and $\sim 100 \mathrm{~m}$ above the valley floor. Hence, Laguna Casercocha does not act as local base level for the studied fans. Downstream of Laguna Casercocha,
Río Tinquimayo flows in a northwesterly direction (Fig. 2a) and eventually enters the Amazonian basin (Fig. 1).

\section{Glacial history of the region}

During the Pleistocene and Holocene, glaciers shaped the region surrounding the Ampatune and Mallma alluvial fans, leaving behind a succession of moraines (Mercer and Palacios, 1977; Goodman et al., 2001; Mark et al., 2002; Ehlers and Gibbard, 2004; Ehlers et al., 2011; Kelly et al., 2012) and glaciofluvial deposits such as the sedimentary fill of the Ocongate basin (Cabrera et al., 1991). The approximate 

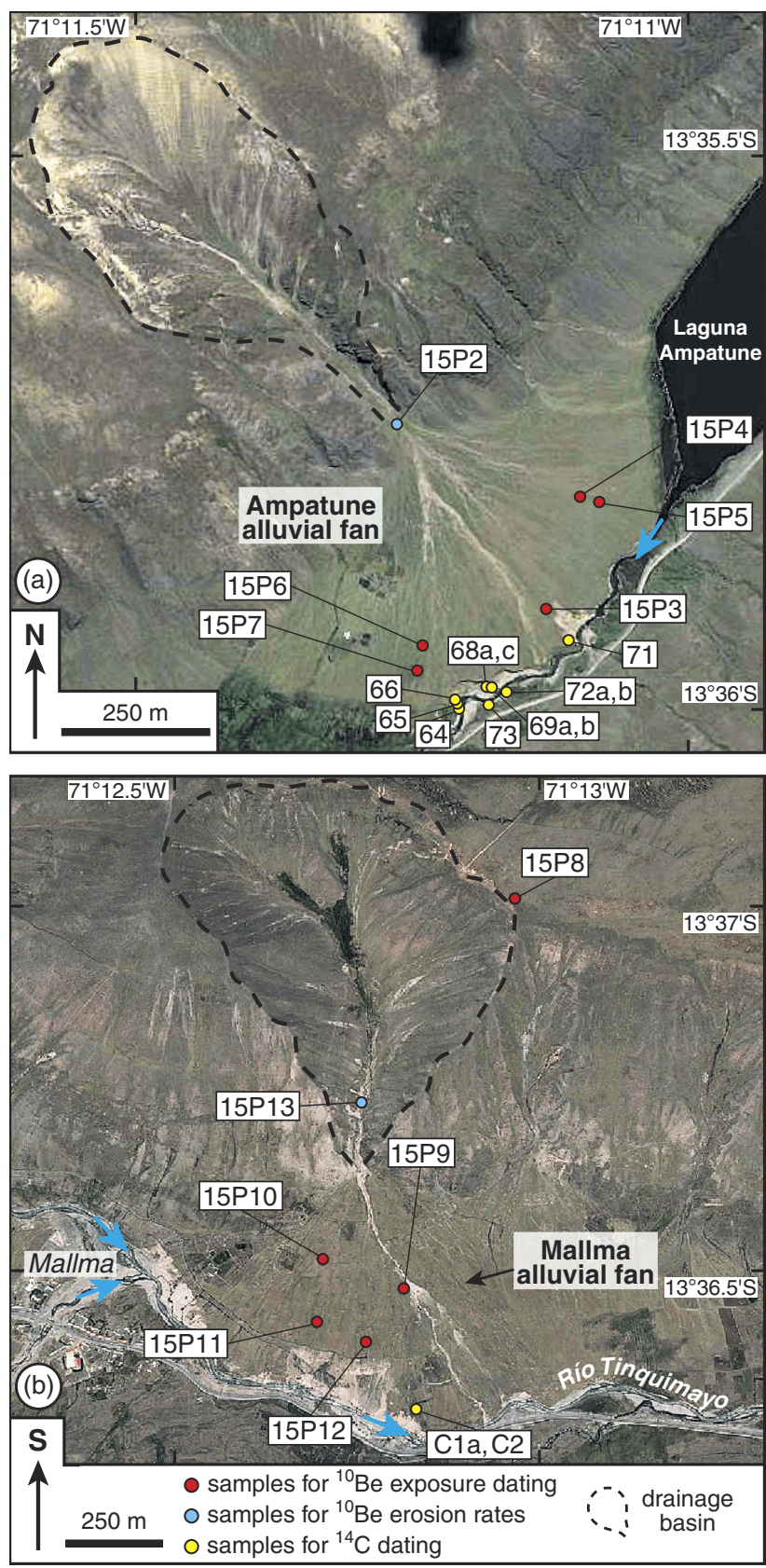

Figure 4. Satellite images of the Ampatune alluvial fan (a), which impounds the Laguna Ampatune, and the Mallma alluvial fan (b) (note that in this image south is upwards). Dashed black line indicates the drainage basin of the respective fan. Blue arrows indicate flow directions of rivers. Red, blue, and yellow points mark sampling sites (with corresponding sample numbers) for ${ }^{10} \mathrm{Be}$ exposure age dating, for ${ }^{10} \mathrm{Be}$-derived catchment-wide erosion rates, and for ${ }^{14} \mathrm{C}$ dating, respectively. Sample numbers are written in the white boxes.

position of the western ice margin during the LGM is shown in Figure 2a by the dashed white line (Ehlers et al., 2011). The kettle lake Laguna Casercocha (3980m elevation) formed near the ice margin on a broad moraine crest as a result of deglaciation (Goodman et al., 2001) (Fig. 2a, b). In a drillcore of the lake sediments, the oldest organic material has an uncalibrated radiocarbon age of $15,640 \pm 100{ }^{14} \mathrm{C}$ yr BP
(Goodman et al., 2001). Calibration with the OxCal program (version 4.3; Bronk Ramsey, 2009) yielded an age range of 19,077-18,627 cal yr BP. This minimum age for glacier retreat is consistent with an age of $20 \mathrm{ka}$ for the LGM in the Cordillera Vilcanota (Mark et al., 2002). The moraine deposits at Laguna Casercocha are correlative with other U3 (= Marine Oxygen Isotope Stage 2) moraines and glacial deposits that occur on the northwestern flank of the Cordillera Vilcanota (Mercer and Palacios, 1977; Goodman et al., 2001; Mark et al., 2002; La Frenierre et al., 2011).

The inferred flow direction of the ice through the valleys containing the Ampatune and Mallma fans is depicted in Figure 2b. During the LGM, a glacier flowed from the Qullqip'unqu mountains to the south and through the area of the Ampatune fan (which is $\sim 9 \mathrm{~km}$ away from the presentday ice margin). About $2 \mathrm{~km}$ farther downstream there was a confluence with a major glacier originating from the central Cordillera Vilcanota (Fig. 2b). This glacier occupied the large valley, where the Río Tinquimayo is flowing today. The Mallma fan is located just downstream of this confluence. From here the valley glacier flowed westward and reached the area of the Laguna Casercocha (Fig. 2b). The valleys have a parabolic cross-sectional shape, which indicates that the LGM glaciers have removed any pre-LGM sediments from the valley floors and the adjacent hillslopes. In summary, the Ampatune and Mallma fans formed after the retreat of the LGM glaciers that occupied the valley between Laguna Casercocha and the two fans.

\section{Lithologies in the fan catchments}

The Palaeozoic bedrock in the tributary catchments of the Ampatune and Mallma fans consists of low-grade metasedimentary rocks of the Ordovician Sandia Formation (Fig. 3a), which is made up of quartzites, phyllites, and schists (Sanchez and Zapata, 2002; Spiske et al., 2006). In addition, glaciofluvial sediments with a thickness of several tens of metres are exposed in the upper parts of both catchments. In the 1:100,000 scale geologic map Ocongate (Sanchez and Zapata, 2002), these sediments are depicted as Pleistocene moraine deposits (Fig. 3a). In satellite images they can be recognized by their light yellowish colour (Fig. 2c). Although the age of these sediments is unknown, the observation that they cover parts of the high plain into which the glacial valleys have been incised (Fig. 2c) suggests that they are rather old and probably mid-Pleistocene in age. The clast-supported sediments show a wide grain-size spectrum and contain rounded pebbles of quartzite and phyllite from the Sandia Formation, but also angular to subangular cobbles and boulders of gneiss, granite, porphyroid, and red sandstone (Sanchez and Zapata, 2002), which are derived from Precambrian basement and Mesozoic magmatic and sedimentary rocks exposed in the Cordillera Vilcanota and the Qullqip'unqu mountains (Fig. 2b). In the upper Ampatune catchment, the glaciofluvial deposits consist of weakly consolidated conglomerates that are easily eroded and transported downslope 
(Fig. 3b). In the Mallma catchment, the sediments are more coarse grained and more consolidated (Fig. 3b, c).

Erosion of the two catchments led to the transport of boulders from the Pleistocene glaciofluvial sediments onto the surfaces of both fans. Boulders on the Ampatune fan consist mainly of reddish porphyroids and typically have a size of up to $1 \mathrm{~m}$, whereas those on the Mallma fan are larger in size $(1-2 \mathrm{~m})$ and consist predominantly of granitic and greyish porphyric volcanic rocks. There is no evidence for recent rockfalls in both catchments. Debris flows from the catchments to the active channels of the fans occur, as indicated by debris-flow levée deposits on the fans.

\section{METHODS AND SAMPLING STRATEGY}

Sedimentologic observations were made at the cliffs at the distal portions of the Ampatune and Mallma fans. To infer the depositional processes as well as the spatiotemporal evolution of the fans, we followed the standard nomenclature of Miall (1996) to classify the different lithofacies types and architectural elements and to interpret them in terms of the depositional environment (e.g., Franke et al., 2014; Meinsen et al., 2014; Ventra and Nichols, 2014).

To assess the age and sedimentation history of the Ampatune and Mallma fans, we applied ${ }^{10} \mathrm{Be}$ surface exposure dating to boulders present on the fan surfaces and used radiocarbon dating to constrain the age of depositional units below the surface of the two fans. As the ${ }^{10} \mathrm{Be}$ samples were collected in 2015 and the calibrated ${ }^{14} \mathrm{C}$ ages are reported relative to $\mathrm{AD} 1950$, there is a difference of $65 \mathrm{yr}$ between the ${ }^{10} \mathrm{Be}$ and ${ }^{14} \mathrm{C}$ time scales. This minor age difference does not affect any of the conclusions of this study.

We also took two stream-sediment samples near the apex of both fans to determine spatially averaged ${ }^{10} \mathrm{Be}$ erosion rates for the catchment areas of the fans. Furthermore, we estimated the fan volumes and used satellite images of the well-preserved Ampatune fan to map fan lobes of different ages. In the following, we describe these methods and procedures in more detail before presenting the results in the next section.

\section{${ }^{10} \mathrm{Be}$ exposure dating and catchment-wide erosion rates}

To place constraints on the timing of fan lobe deposition on the two alluvial fans, we took nine samples from boulders protruding the fan surfaces for ${ }^{10} \mathrm{Be}$ exposure dating (Figs. 4, 5). Five samples were collected from the Ampatune fan (15P3-15P7; Fig. 4a) and four from the Mallma fan (15P915P12; Fig. 4b). In the distal part of the central Ampatune fan, sample $15 \mathrm{P} 3$ was taken from an angular quartzite boulder with a size of $70 \times 55 \mathrm{~cm}$ that protruded the fan surface by $\sim 25 \mathrm{~cm}$. The four other samples from this fan were taken from boulders of reddish, porphyric volcanic rocks rich in quartz phenocrysts. Samples 15P6 and 15P7 (Fig. 5a, b) were collected in the southern part of the Ampatune fan. Sample 15P6 is from the largest boulder (size:
$100 \times 80 \mathrm{~cm}$ ) out of an assemblage of several boulders. The boulder from which sample 15P7 was chiselled off had a similar size as the one used for 15P3. Samples 15P4 and 15P5 are from boulders in the northeastern part of the fan (Fig. 4a). Both boulders were $\sim 65 \mathrm{~cm}$ long and $\sim 35 \mathrm{~cm}$ wide and protruded the alluvial fan surface by $\sim 20 \mathrm{~cm}$ and $\sim 10 \mathrm{~cm}$, respectively (Fig. 5c, d).

The four boulders sampled on the Mallma fan are composed of granitic rocks $(15 \mathrm{P} 9,15 \mathrm{P} 10$, and $15 \mathrm{P} 11)$ or greyish, quartz-bearing volcanic rocks (15P12). Sample 15P9 was taken from the top of a 1.8-m-high boulder located in the central part of the alluvial fan near a prominent channel (Fig. $4 b$; Supplementary Fig. 1). Sample 15 P10 is from a flattopped boulder near the fan apex (Fig. 4b), which is $2 \mathrm{~m}$ long and $1.5 \mathrm{~m}$ wide and stands $\sim 0.9 \mathrm{~m}$ above the fan surface (Fig. 5f). Samples 15P11 and 15P12 were chiselled off from boulders located in the more distal part of the fan (Fig. 4b). Sample 15P11 is from a boulder with a length of $\sim 1.6 \mathrm{~m}$ and a width of $\sim 1.4 \mathrm{~m}$ that stands up to $\sim 40 \mathrm{~cm}$ above the fan surface. The boulder used for sample $15 \mathrm{P} 12$ was only slightly smaller $(1.1 \times 1.1 \mathrm{~m})$ and had its highest point $\sim 15 \mathrm{~cm}$ above the fan surface (Fig. 5e).

In addition to the samples from rock boulders on the fan surfaces, we took one sample (15P8) from a quartzite boulder near the southwestern boundary of the Mallma catchment (Fig. 4b). The boulder protrudes the soil-covered surface of the high plateau above the Mallma catchment (Fig. 6a) and was collected to give a minimum age for this sharply incised palaeoplain (Fig. 6b). Moreover, the sample also provides a minimum age constraint for the glaciofluvial sediments in the upper parts of both catchments. Finally, we collected two samples of stream sediment (15P2 and 15P13) to determine spatially integrated erosion rates for the catchments of the Ampatune and Mallma fans (Fig. 4).

Sample preparation and chemical separation of ${ }^{10} \mathrm{Be}$ from quartz was carried out at the Institute of Geology and Palaeontology, University of Münster. After crushing the boulder samples, all samples were sieved and washed. Subsequently, the $250-500 \mu \mathrm{m}$ grain size fraction was split into a magnetic and a nonmagnetic fraction using a Frantz magnetic separator. The subsequent cleaning of the nonmagnetic fraction containing the quartz consisted of one etching step in $6 \mathrm{M} \mathrm{HCl}$ at $80^{\circ} \mathrm{C}$ and four etching steps in dilute $(1 \%)$ $\mathrm{HF} / \mathrm{HNO}_{3}$ in an ultrasonic bath heated to $80^{\circ} \mathrm{C}$ (Kohl and Nishiizumi, 1992). The samples were then etched once in aqua regia and 8M HF (Goethals et al., 2009). For Be extraction, about $20 \mathrm{~g}$ of quartz from each sample was dissolved in $40 \% \mathrm{HF}$ after the addition of $0.3 \mathrm{mg}$ of Be carrier. Following complete dissolution, all samples were converted into chloride form using $6 \mathrm{M} \mathrm{HCl}$. Beryllium was separated by successive anion and cation exchange columns and precipitated as $\mathrm{Be}(\mathrm{OH})_{2}$ at $\mathrm{pH} 8-9$. Following the transformation to $\mathrm{BeO}$ at $1000^{\circ} \mathrm{C}$, targets were prepared by mixing of the $\mathrm{BeO}$ with $\mathrm{Nb}$ powder.

All samples were analysed at the centre for accelerator mass spectrometry at the University of Cologne, Germany (Dewald et al., 2013). The ${ }^{10} \mathrm{Be}$ exposure ages (Table 1) and 

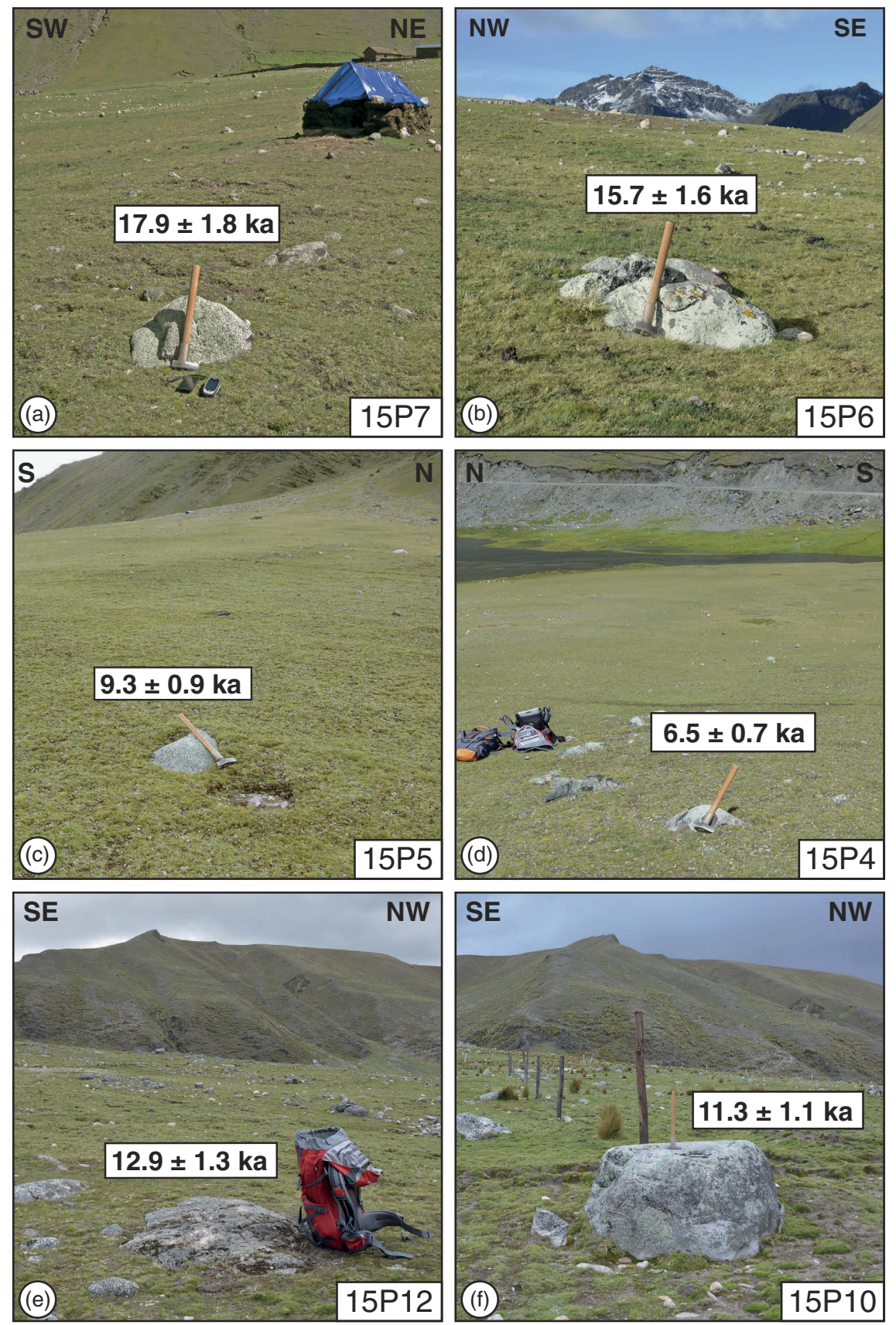

Figure 5. Examples of boulders sampled for ${ }^{10}$ Be exposure dating on the Ampatune (a-d) and Mallma (e-f) alluvial fans. Sample number is given in the bottom right corner of each picture. Exposure ages are shown with external errors.

catchment-wide erosion rates (Table 2) were calculated with version 2.3 of the CRONUS-Earth online calculator (http:// hess.ess.washington.edu/). All exposure ages were calculated under the assumption of no erosion and no cover by snow.

\section{Radiocarbon dating}

For ${ }^{14} \mathrm{C}$ dating, we collected organic-rich samples from finegrained sedimentary beds of peat, soil, or sandy silt (Table 3 ). In one case (sample 69b), charcoal flakes were used. The sampled peat layers have grown directly on the fan surface in a peat bog environment with good drainage without standing water bodies. The sampled beds are exposed in cliffs at the distal ends of the fans (Fig. 7), and all samples were taken $0.8 \mathrm{~m}$ to $6 \mathrm{~m}$ below the surface of the respective fan.

Sample preparation and ${ }^{14} \mathrm{C}$ analysis of the 11 samples from the Ampatune fan were carried out at the Leibniz Institute for Applied Geophysics, Hannover, Germany. Using conventional ${ }^{14} \mathrm{C}$ dating, the specific activity of ${ }^{14} \mathrm{C}$ was measured radiometrically by proportional counters (Geyh, 1990, 2005). Preparation and analysis of the two ${ }^{14} \mathrm{C}$ samples from the Mallma fan were carried out at the CurtEngelhorn-Centre Archaeometry $\mathrm{GmbH}$ in Mannheim. The two samples were treated with $\mathrm{HCl}, \mathrm{NaOH}$, and $\mathrm{HCl}$ using 

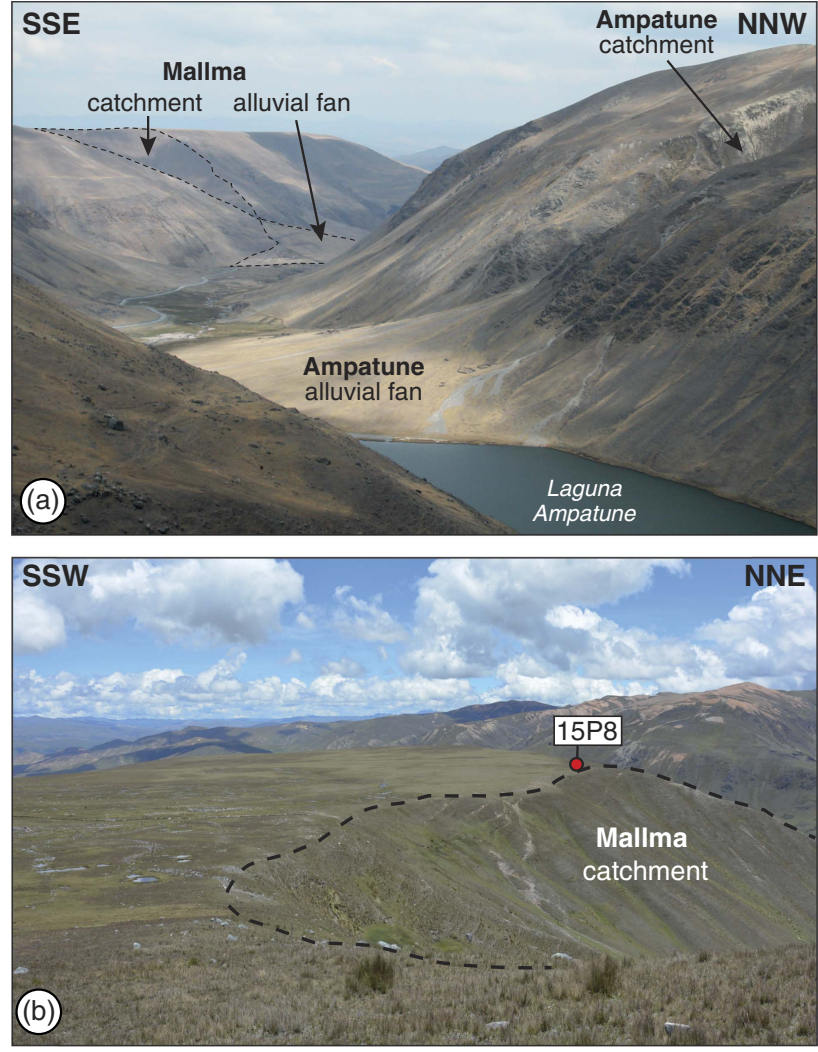

Figure 6. (a) Overview picture on the two studied alluvial fans. View is downvalley to the west-southwest. Note the flat surface that delimits the uppermost part of the Mallma catchment. (b) Picture of the flat surface above the Mallma catchment. View is towards west-northwest. Dashed black line indicates boundary of Mallma catchment. Red dot marks location of sample 15P8.

the acid/base/acid method. The indissoluble fraction was burned in an elemental analyser to obtain $\mathrm{CO}_{2}$, which was subsequently reduced to graphite. The ${ }^{14} \mathrm{C}$ concentration was measured with the MICADAS-accelerator of the KlausTschira-Laboratory for Radiometric Dating Methods of the Ruprecht-Karls-Universität Heidelberg.

All uncalibrated ${ }^{14} \mathrm{C}$ ages are normalized to a $\delta^{13} \mathrm{C}$ value of $-25 \%$ (Stuiver and Polach, 1977) and are reported with $1 \sigma$ errors (Table 3). The calibrated ${ }^{14} \mathrm{C}$ ages were calculated with the OxCal program (version 4.3; Bronk Ramsey, 2009) using the Southern Hemisphere SHCal13 radiocarbon calibration curve (Hogg et al., 2013). The calibrated age ranges and their median are given with $2 \sigma$ errors. In addition, we report mean ages with symmetric error $(2 \sigma)$ (Table 3 ). All calibrated ${ }^{14} \mathrm{C}$ ages and age ranges are given in years BP (before present, i.e., before $\mathrm{AD}$ 1950).

\section{Estimation of fan volumes and mapping of the Ampatune fan}

The volume of the two alluvial fans was determined using the software PETREL of Schlumberger. The initial valley geometry beneath the fans (i.e., after the retreat of the glaciers after the LGM) was reconstructed by extrapolating the slopes of the valleys. The upper parts of the valley slopes are still recognizable above the fan. In addition, field observations show that the sediments in the upper portion of the fan are in direct contact with the bedrock that forms the slope of the parabolic valley. The parabolic valley shape (Fig. 6a) and the fact that the valley bottom is devoid of a significant valley fill indicates that the valley was formed by glacial erosion. After the last glaciation, the valley was locally covered by some colluvium. Taken together, these observations indicate that the original valley now containing the Ampatune and Mallma fans was cleaned out by the LGM glacier. For the calculation of the post-LGM fan volume, it is hence reasonable to assume that the exposed valley slopes can be extrapolated along the valleys beneath the Ampatune and Mallma fans to reconstruct the basis of the fans.

The relatively pristine fan surface of the Ampatune fan allowed the use of satellite images together with field observations to subdivide the entire alluvial fan into fan lobes with different relative ages. The lobes were distinguished in terms of increasing coverage with fine-grained sediments, which results in reduction of surface roughness and patchy distribution of colours; in terms of increasing overgrowth with grass and moss, resulting in different intensity of modern peat formation; and in terms of different grey shading caused by weathering effects of bare rock surfaces. In the satellite images, relatively young parts of the fan are light grey in colour and have a blotty irregular appearance, because of the wide grain-size spectrum of the fan deposits and the lack of vegetation and missing fine-grained sediments between larger cobbles and boulders, attributable to outwash-effects. With time, the rather bright grey colours become darker and more homogeneous, owing to weathering, the growth of grass, and the development of thin soil and modern peat. Because of these alteration processes, the initial morphology of the channel-levée systems flattens and surface roughness decreases, which results in less patchy distribution of greenish-greyish colours. Apart from the surface structure, we identified fan lobes also based on their size, shape, and spatial distribution to obtain coherent and geologically meaningful genetic units. For the Mallma fan, the establishment of a relative chronology of different fan lobes is not possible owing to the anthropogenic alteration of some parts of the fan by farming.

\section{RESULTS}

\section{Description of the Ampatune and Mallma fans and interpretation}

Sediments exposed in the cliffs along the distal part of the Ampatune fan can be divided into two main gravel lithofacies types (cf. Miall, 1996): (1) massive, matrix-supported, and poorly sorted gravel deposits, partly fining upwards, and (2) clast-supported, horizontally stratified, and moderately sorted gravel with some beds showing imbrication and/or inverse grading. In the latter unit, pebbles appear cleaned, and some beds are characterized by an open framework. The two types of 
Table 1. Information on ${ }^{10} \mathrm{Be}$ exposure dating of rock boulders of the Ampatune and Mallma alluvial fans.

\begin{tabular}{|c|c|c|c|c|c|c|c|c|c|c|c|c|c|}
\hline $\begin{array}{l}\text { Sample } \\
\text { ID }\end{array}$ & $\begin{array}{l}\text { Latitude } \\
\left({ }^{\circ} \mathrm{S}\right)\end{array}$ & $\begin{array}{l}\text { Longitude } \\
\left({ }^{\circ} \mathrm{W}\right)\end{array}$ & $\begin{array}{l}\text { Elevation } \\
\text { (m) }\end{array}$ & $\begin{array}{c}\text { Height } \\
\text { above ground } \\
(\mathrm{cm})\end{array}$ & $\begin{array}{c}\text { Sample } \\
\text { thickness } \\
(\mathrm{cm})\end{array}$ & $\begin{array}{c}\text { Topographic } \\
\text { shielding }\end{array}$ & $\begin{array}{c}\text { Total } \\
\text { shielding }^{\mathrm{a}}\end{array}$ & $\begin{array}{c}{ }^{10} \mathrm{Be} \\
\text { concentration }^{\mathrm{b}} \\
\left(10^{3} \mathrm{at} / \mathrm{g}\right)\end{array}$ & $\begin{array}{c}\text { Production rate } \\
\text { (spallation) } \\
\text { (at/g/yr) }\end{array}$ & $\begin{array}{c}\text { Production } \\
\text { rate (muons) } \\
(\mathrm{at} / \mathrm{g} / \mathrm{yr})\end{array}$ & $\begin{array}{c}{ }^{10} \mathrm{Be} \\
\text { exposure age } \\
\text { (ka) }\end{array}$ & $\begin{array}{c}\text { Internal } \\
\text { uncertainty }^{\mathrm{c}} \\
(\mathrm{ka})\end{array}$ & $\begin{array}{c}\text { External } \\
\text { uncertainty }^{\mathrm{c}} \\
(\mathrm{ka})\end{array}$ \\
\hline \multicolumn{14}{|c|}{ Ampatune alluvial fan } \\
\hline $15 \mathrm{P} 3$ & 13.5980 & 71.1859 & 4290 & 25 & 6 & 0.9845 & 0.9371 & $326 \pm 12$ & 33.64 & 0.257 & 9.36 & \pm 0.36 & \pm 0.94 \\
\hline $15 \mathrm{P} 4$ & 13.5963 & 71.1856 & 4301 & 20 & 2 & 0.9844 & 0.9683 & $232.8 \pm 8.7$ & 34.93 & 0.263 & 6.46 & \pm 0.25 & \pm 0.65 \\
\hline $15 \mathrm{P} 5$ & 13.5964 & 71.1854 & 4298 & 10 & 2 & 0.9843 & 0.9682 & $336 \pm 12$ & 34.88 & 0.263 & 9.28 & \pm 0.34 & \pm 0.93 \\
\hline $15 \mathrm{P} 6$ & 13.5986 & 71.1880 & 4293 & 40 & 4 & 0.9857 & 0.9538 & $561 \pm 20$ & 34.29 & 0.259 & 15.71 & \pm 0.57 & \pm 1.56 \\
\hline $15 \mathrm{P} 7$ & 13.5989 & 71.1880 & 4289 & 40 & 2 & 0.9860 & 0.9698 & $658 \pm 22$ & 34.80 & 0.262 & 17.86 & \pm 0.64 & \pm 1.77 \\
\hline \multicolumn{14}{|c|}{ Mallma alluvial fan } \\
\hline $15 \mathrm{P} 9$ & 13.6076 & 71.2142 & 4174 & 180 & 3 & 0.9933 & 0.9691 & $1514 \pm 49$ & 32.98 & 0.253 & 37.8 & \pm 1.5 & \pm 3.7 \\
\hline $15 \mathrm{P} 10$ & 13.6082 & 71.2122 & 4191 & 90 & 1 & 0.9929 & 0.9848 & $395 \pm 14$ & 33.78 & 0.258 & 11.31 & \pm 0.42 & \pm 1.13 \\
\hline $15 \mathrm{P} 11$ & 13.6068 & 71.2122 & 4156 & 40 & 5 & 0.9925 & 0.9525 & $439 \pm 15$ & 32.15 & 0.250 & 13.27 & \pm 0.47 & \pm 1.32 \\
\hline $15 \mathrm{P} 12$ & 13.6063 & 71.2134 & 4146 & 15 & 1 & 0.9925 & 0.9844 & $438 \pm 15$ & 33.07 & 0.255 & 12.87 & \pm 0.46 & \pm 1.28 \\
\hline \multicolumn{14}{|c|}{ Quartzite boulder from plain above Mallma fan } \\
\hline $15 \mathrm{P} 8$ & 13.6166 & 71.2161 & 4532 & 25 & 3 & 0.9999 & 0.9755 & $11,680 \pm 360$ & 39.04 & 0.276 & 239 & \pm 11 & \pm 25 \\
\hline
\end{tabular}

${ }^{\mathrm{a}}$ The total shielding factor includes the corrections for both sample thickness and topographic shielding.

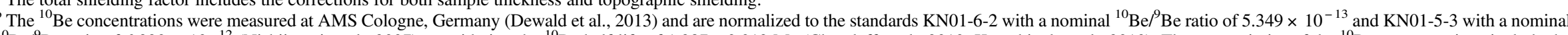

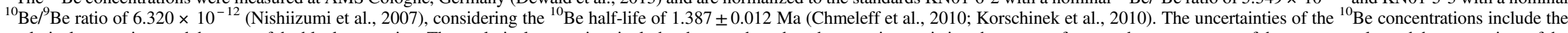

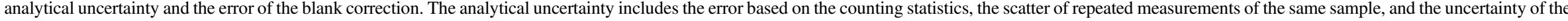
standard normalisation.

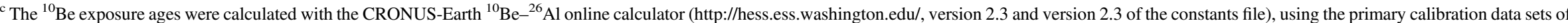

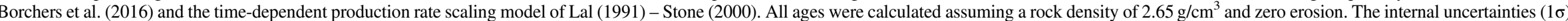
include the analytical errors and the error of the blank correction, whereas external uncertainties $(1 \sigma)$ also include the systematic uncertainty of the sea-level high-latitude ${ }^{10} \mathrm{Be}$ production rate. 
Table 2. ${ }^{10} \mathrm{Be}$ concentrations and catchment-wide erosion rates in the drainage basins of the Ampatune and Mallma alluvial fans.

\begin{tabular}{|c|c|c|c|c|c|c|c|c|c|c|c|c|}
\hline \multirow{2}{*}{$\begin{array}{l}\text { Sample } \\
\text { ID }\end{array}$} & \multirow[b]{2}{*}{$\begin{array}{l}\text { Latitude } \\
\qquad\left({ }^{\circ} \mathrm{S}\right)\end{array}$} & \multirow[b]{2}{*}{$\begin{array}{l}\text { Longitude } \\
\qquad\left({ }^{\circ} \mathrm{W}\right)\end{array}$} & \multirow{2}{*}{$\begin{array}{c}\text { Elevation of } \\
\text { sampling } \\
\text { site } \\
\text { (m) }\end{array}$} & \multirow{2}{*}{$\begin{array}{c}\text { Mean } \\
\text { catchment } \\
\text { elevation } \\
\text { (m) }\end{array}$} & \multirow{2}{*}{$\begin{array}{l}\text { Topographic } \\
\text { shielding } \\
\text { factor }^{\mathrm{a}}\end{array}$} & \multirow{2}{*}{$\begin{array}{c}{ }^{10} \mathrm{Be} \\
\text { concentration }^{\mathrm{b}} \\
\left(10^{4} \mathrm{at} / \mathrm{g}\right)\end{array}$} & \multicolumn{2}{|c|}{ Production rate } & \multirow{2}{*}{$\begin{array}{l}\text { Erosion } \\
\text { rate }^{c} \\
(\mathrm{~mm} / \mathrm{ka})\end{array}$} & \multirow{2}{*}{$\begin{array}{c}\text { Internal } \\
\text { uncertainty } \\
(1 \sigma) \\
(\mathrm{mm} / \mathrm{ka})\end{array}$} & \multirow{2}{*}{$\begin{array}{c}\text { External } \\
\text { uncertainty } \\
(1 \sigma) \\
(\mathrm{mm} / \mathrm{ka})\end{array}$} & \multirow{2}{*}{$\begin{array}{l}\text { Time } \\
\text { scale } \\
\text { (ka) }\end{array}$} \\
\hline & & & & & & & $\begin{array}{l}\text { (spallation) } \\
\text { (at/g/yr) }\end{array}$ & $\begin{array}{l}\text { (muons) } \\
\text { (at/g/yr) }\end{array}$ & & & & \\
\hline \multicolumn{13}{|c|}{ Ampatune alluvial fan } \\
\hline $15 \mathrm{P} 2$ & 13.5953 & 71.1882 & 4363 & 4578 & 0.9826 & $10.55 \pm 0.48$ & 40.13 & 0.285 & 256 & 12 & 24 & 2.5 \\
\hline \multicolumn{13}{|c|}{ Mallma alluvial fan } \\
\hline $15 \mathrm{P} 13$ & 13.6120 & 71.2132 & 4250 & 4452 & 0.9899 & $80.20 \pm 2.72$ & 38.23 & 0.276 & 31.6 & 1.1 & 2.8 & 20 \\
\hline
\end{tabular}

a The topographic shielding factors were calculated using a $30 \mathrm{~m}$ satellite radar topographic mission (SRTM) digital elevation model and the MATLAB script of Greg Balco (http://depts.washington.edu/cosmolab/shielding.m).

${ }^{\mathrm{b}}$ The ${ }^{10} \mathrm{Be}$ concentrations were measured at AMS Cologne, Germany (Dewald et al., 2013) and are normalised to the standards KN01-6-2 with a nominal ${ }^{10} \mathrm{Be} /{ }^{9} \mathrm{Be}$ ratio of $5.349 \times 10^{-13}$ and KN01-5-3 with a nominal ${ }^{10} \mathrm{Be} /{ }^{9} \mathrm{Be}$ ratio of $6.320 \times 10^{-12}$ (Nishiizumi et al., 2007), considering the ${ }^{10} \mathrm{Be}$ half-life of $1.387 \pm 0.012 \mathrm{Ma}$ (Chmeleff et al., 2010; Korschinek et al., 2010). The uncertainties of the ${ }^{10}$ Be concentrations include the analytical uncertainty and the error of the blank correction. The analytical uncertainty includes the error based on the counting statistics, the scatter of repeated measurements of the same sample, and the uncertainty of the standard normalisation.

${ }^{\mathrm{c}}$ Erosion rates were calculated with the CRONUS-Earth ${ }^{10} \mathrm{Be}-{ }^{26} \mathrm{Al}$ online calculator (http://hess.ess.washington.edu/; version 2.3 and version 2.3 of the constants file), using the primary calibration data sets of Borchers et al. (2016) and the time-invariant production rate scaling model of Lal (1991) - Stone (2000). The internal uncertainties $(1 \sigma)$ include the analytical errors and the error of the blank correction, whereas external uncertainties $(1 \sigma)$ also include the systematic uncertainty of the sea-level high-latitude ${ }^{10} \mathrm{Be}$ production rate. For the calculation, we used a density of $2.5 \mathrm{~g} / \mathrm{cm}^{3}$ and the mean elevation of the catchments. The time over which the erosion rate integrates is calculated by dividing the absorption depth scale (i.e., $64 \mathrm{~cm}$ for a density of $2.5 \mathrm{~g} / \mathrm{cm}^{3}$ ) by the erosion rate.

Table 3. Information on ${ }^{14} \mathrm{C}$ dating of organic material of the Ampatune and Mallma alluvial fans.

\begin{tabular}{|c|c|c|c|c|c|c|c|}
\hline Sample ID & $\begin{array}{l}\text { Latitude } \\
\left({ }^{\circ} \mathrm{S}\right)\end{array}$ & $\begin{array}{c}\text { Longitude } \\
\left({ }^{\circ} \mathrm{W}\right)\end{array}$ & $\begin{array}{l}\text { Depth below } \\
\text { fan surface } \\
\text { (m) }\end{array}$ & $\begin{array}{l}\text { Sample } \\
\text { material }\end{array}$ & $\begin{array}{c}\text { Uncalibrated } \\
{ }^{14} \mathrm{C} \text { age }^{\mathrm{a}} \\
\text { (yr BP) }\end{array}$ & $\begin{array}{c}\text { Calibrated age } \\
\text { range }^{\mathrm{b}} \\
(\text { cal yr BP })\end{array}$ & $\begin{array}{c}\text { Median } \\
\text { age }^{\mathrm{b}} \\
\text { (cal yr BP) }\end{array}$ \\
\hline \multicolumn{8}{|c|}{ Ampatune alluvial fan } \\
\hline 64 & 13.5994 & 71.1872 & 4 & Peat & $8920 \pm 65$ & $10,194-9708$ & 9992 \\
\hline 65 & 13.5993 & 71.1873 & 2 & Peat & $8770 \pm 60$ & $10,114-9541$ & 9709 \\
\hline 66 & 13.5993 & 71.1873 & 4 & Peat & $8990 \pm 55$ & $10,234-9897$ & 10,055 \\
\hline $68 \mathrm{a}$ & 13.5991 & 71.1868 & 6 & Peat & $9400 \pm 45$ & $10,711-10,425$ & 10,578 \\
\hline $68 c$ & 13.5991 & 71.1868 & 5 & Peat & $9115 \pm 45$ & $10,381-10,171$ & 10,231 \\
\hline $69 \mathrm{a}$ & 13.5991 & 71.1867 & 5 & Peat & $9300 \pm 80$ & $10,654-10,243$ & 10,434 \\
\hline $69 b$ & 13.5991 & 71.1867 & 4 & Charcoal & $9100 \pm 65$ & $10,413-9930$ & 10,222 \\
\hline 71 & 13.5984 & 71.1854 & 6 & Soil & $8260 \pm 200$ & 9543-8607 & 9162 \\
\hline $72 \mathrm{a}$ & 13.5992 & 71.1865 & 2 & Peat & $9400 \pm 80$ & $10,782-10,270$ & 10,573 \\
\hline $72 b$ & 13.5992 & 71.1865 & 1.5 & Peat & $9000 \pm 80$ & $10,247-9777$ & 10,052 \\
\hline 73 & 13.5993 & 71.1867 & 1 & Peat & $1180 \pm 45$ & 1178-956 & 1030 \\
\hline \multicolumn{8}{|c|}{ Mallma alluvial fan } \\
\hline $\mathrm{C} 1 \mathrm{a}$ & 13.6047 & 71.2145 & 0.8 & Sandy silt & $9481 \pm 33$ & $10,770-10,566$ & 10,669 \\
\hline $\mathrm{C} 2$ & 13.6047 & 71.2145 & 1.0 & Sandy silt & $10,064 \pm 40$ & $11,750-11,311$ & 11,511 \\
\hline
\end{tabular}

${ }^{a}$ Uncalibrated ${ }^{14} \mathrm{C}$ ages with $1 \sigma$ errors are given as years BP (before present, i.e., before AD 1950). The samples from the Ampatune fan were analysed at the Leibniz Institute for Applied Geophysics, Hannover, Germany. The samples from the Mallma fan were analysed at the MICADAS accelerator of the KlausTschira-Laboratory for Radiometric Dating Methods, Mannheim, Germany.

${ }^{\mathrm{b}}$ The calibrated ${ }^{14} \mathrm{C}$ age ranges ( $2 \sigma$ uncertainty) and the median ages were calculated with the OxCal program (version 4.3; Bronk Ramsey, 2009) using the Southern Hemisphere SHCal13 radiocarbon calibration curve (Hogg et al., 2013). Calibrated ${ }^{14} \mathrm{C}$ ages are given as years BP (before present, i.e., before AD 1950).

depositional units are typically 0.5 to $1 \mathrm{~m}$ thick. Between the gravel beds, thin layers of sand or silt are often associated with weakly developed palaeosols. These fine-grained intercalations and palaeosols have a lateral extent of tens to hundreds of metres and formed before the next gravel unit was deposited. Peat and initial soil formation are also observed in large parts of the modern fan surface, where only some confined channels are active locally. The present-day fan surface is covered by grasses and mosses.
We interpret the matrix-supported gravel units as debrisflow deposits and the clast-supported, better sorted, and cleaner gravels as stream-channel deposits (Blair and McPherson, 1994, 2009; Miall, 1996; Harvey et al., 2005; Nichols, 2009). The dominance of thick gravel beds points to event-controlled deposition, whereas the intercalated fine-grained beds represent overbank flow, waning floods, and/or the later-stage redistribution of fine-grained material on the exposed fan surface (Miall, 1996). The peaty initial palaeosols indicate that the 

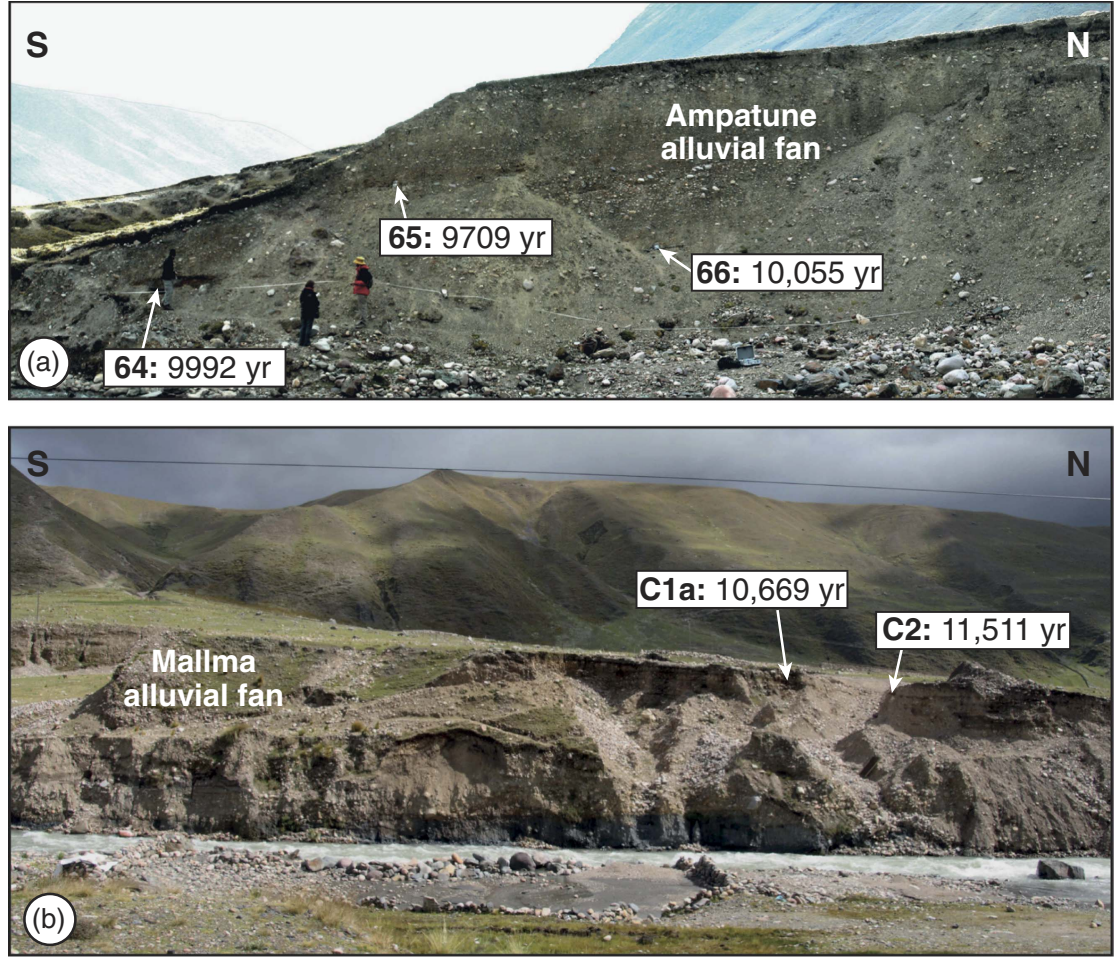

Figure 7. Examples of cliffs sampled for ${ }^{14} \mathrm{C}$ dating at the Ampatune (a) and Mallma (b) alluvial fans. ${ }^{14} \mathrm{C}$ ages are given as calibrated median ages in years BP (for complete age ranges, see Table 3 ) in the white boxes. Sample numbers are written in bold.

depositional inactivity and quiescence lasted at least for decades. Because of the climate conditions at the high altitude of $>4000 \mathrm{~m}$, grasses and mosses have prevailed presumably since the retreat of the glaciers. This vegetation cover may have stabilized the surface during periods of depositional inactivity (cf. Gibling, 2006; Cable et al., 2018); however, it has not significantly influenced the sediment distribution during fan activity periods.

The sediment exposures along the cliffs also allowed a twodimensional analysis of architectural elements. We identified flat unconfined channels, lateral accretion complexes, and levées; sediments include channel fill, sheet flood, and debris flow deposits (cf. Blair and McPherson, 1994, 2009; Harvey et al., 2005; Nichols, 2009). The partial filling of the channels by matrix-supported gravels indicates preferred movement of debris flows along previous pathways. The fine-grained beds may be the product of overbank flow. Alternatively, they may indicate depositional starvation and/or that sedimentation of coarser material was confined to small areas during these periods. The interruption of deposition at a specific site could have also been caused by autocyclic channel switching and lobe abandonment (e.g., Nichols, 2009). Altogether, the outcrops along the cliffs display a multilateral depositional architecture (e.g., Miall, 1996; Gibling, 2006), which indicates a self-organized buildup with switching depositional lobes.

Similar to the Ampatune fan, the sediments of the Mallma fan show units with weakly stratified, moderately sorted gravels and poorly sorted massive gravels, respectively. Some planar cross-bedded gravel units grade into a trough-bedded type. In contrast to the Ampatune fan, matrix-supported gravel beds are more frequent than clast-supported gravels. Outsized subangular to angular boulders are also more frequent and often arranged along depositional boundaries. In general, stratification, sorting, imbrication, and grading are less well developed than in the Ampatune fan. This is supported by the almost exponential grain-size distribution curves for the MalIma fan, whereas the curves for the Ampatune fan are more sigmoidal in shape. Fine-grained beds are rare, and peaty palaeosols are restricted to the upper part of the succession.

The outcrops of the Mallma fan along the cliffs of the Río Tinquimayo show the following architectural elements: channels, lateral accretion complexes, and levées, which mainly comprise channel fill, sheet flood, and debris flow deposits. The coarse-grained mass flow deposits may form thick, amalgamated packages. Because of the rare occurrence of finegrained intercalations, boundaries between architectural elements and depositional units are often blurred. Stacked successions of debris flow deposits reach up to $3 \mathrm{~m}$ in thickness and make up the major part of the outcrop. In the uppermost part, a 1-m-thick package of sheet flood deposits occurs. This unit is separated from the underlying debris flow deposits by fine-grained layers with pedogenic features and a minor humic content. These layers fill depressions of the palaeosurface and are less continuous than those observed at the Ampatune fan.

In conclusion, the Mallma fan is the product of similar depositional processes as the Ampatune fan; however, the dominance of debris flow deposits, multistory channel complexes, and less pronounced periods of depositional quiescence point to a more continuous activity and/or a higher susceptibility to the generation of matrix-supported debris flow 
deposits. The latter may be explained by the higher proportion of unsorted glacigenic material present in the Mallma catchment. This may also be the reason why the sedimentary architecture of the Ampatune fan shows a multilateral character only, whereas the Mallma fan shows multilateral and multistory channel complexes (e.g., Miall, 1996; Gibling, 2006). Neither the sediments of the Mallma nor those of the Ampatune fan show evidence for cryoturbation or structures indicative of permafrost, such as ice-wedge casts or patterned ground.

\section{Results from ${ }^{10} \mathrm{Be}$ and ${ }^{14} \mathrm{C}$ analysis}

The results of the ${ }^{10} \mathrm{Be}$ and ${ }^{14} \mathrm{C}$ analyses are reported in Tables 1-3 and displayed in Figures 7 and 8. In general, ${ }^{10} \mathrm{Be}$ and ${ }^{14} \mathrm{C}$ ages of both alluvial fans are in good agreement. The relative chronology for the different fan lobes of the Ampatune fan (Fig. 8a) shows that distal fan segments of the fan are older, whereas more proximal parts are younger. The exposure ages and the mapping of the different fan lobes yielded consistent results. Samples 15P6 and 15P7 (Fig. 5a, b) are part of the second oldest fan lobe, which was the oldest one being sampled (Fig. 8a). With ${ }^{10} \mathrm{Be}$ exposure ages of $15.7 \pm 1.6 \mathrm{ka}$ and $17.9 \pm 1.8 \mathrm{ka}$, respectively, these two samples yielded the highest ages. The boulders of samples $15 \mathrm{P} 3$ and $15 \mathrm{P} 5$ were deposited as part of a younger fan lobe, which is supported by their nearly identical exposure ages of $9.4 \pm 0.9 \mathrm{ka}$ and $9.3 \pm 0.9 \mathrm{ka}$, respectively (Fig. 8a). One boulder from a still younger fan lobe yielded a lower exposure age of $6.5 \pm 0.7 \mathrm{ka}$. Samples for ${ }^{14} \mathrm{C}$ dating were all taken from cliffs in the fan lobe from which ${ }^{10} \mathrm{Be}$ samples $15 \mathrm{P} 3$ and $15 \mathrm{P} 5$ were collected. Median ${ }^{14} \mathrm{C}$ ages of all samples except one vary between 9162 and 10,578 cal yr BP (Fig. 8a, Table 3). The only exception is sample 73 with a ${ }^{14} \mathrm{C}$ age of $1178-956 \mathrm{cal}$ yr BP. This sample was taken at an erosion bank on the riverside opposite to the fan and belongs to colluvial deposits originating from the opposite side of the valley. We therefore do not further consider the result from sample 73 .

For the Mallma alluvial fan, samples 15P10, 15P11, and $15 \mathrm{P} 12$ from the central and eastern parts of the fan yielded similar ${ }^{10} \mathrm{Be}$ exposure ages of $11.3 \pm 1.1 \mathrm{ka}, 13.3 \pm 1.3 \mathrm{ka}$, and $12.9 \pm 1.3 \mathrm{ka}$, respectively (Fig. 8b). In contrast, the boulder of sample 15P9 has an exposure age of $37.8 \pm 3.7 \mathrm{ka}$, which is the highest age of all sampled boulders. As this boulder is located near the main active channel of the Mallma fan and has a ${ }^{10} \mathrm{Be}$ age that exceeds the post-LGM fan formation, sample 15P9 contains a significant inherited nuclide component. Furthermore, radiocarbon dating of samples $\mathrm{C} 1 \mathrm{a}$ and $\mathrm{C} 2$ from the distal part of the Mallma fan yielded ages of 10,770-10,566 and 11,750-11,311 cal yr BP, respectively (Fig. 8b, Table 3). As this indicates that the boulder is embedded in younger fan sediments, its apparent pre-LGM age does not date deposition but is attributable to an inherited component; we will therefore exclude the result for sample 15P9 from the further discussion.

The ${ }^{10} \mathrm{Be}$ exposure age for sample $15 \mathrm{P} 8$ from the quartzite boulder on the high plateau at the upper boundary of the Mallma catchment is $239 \pm 25 \mathrm{ka}$ (Fig. 8b). It provides a minimum age for the formation of this palaeosurface as well
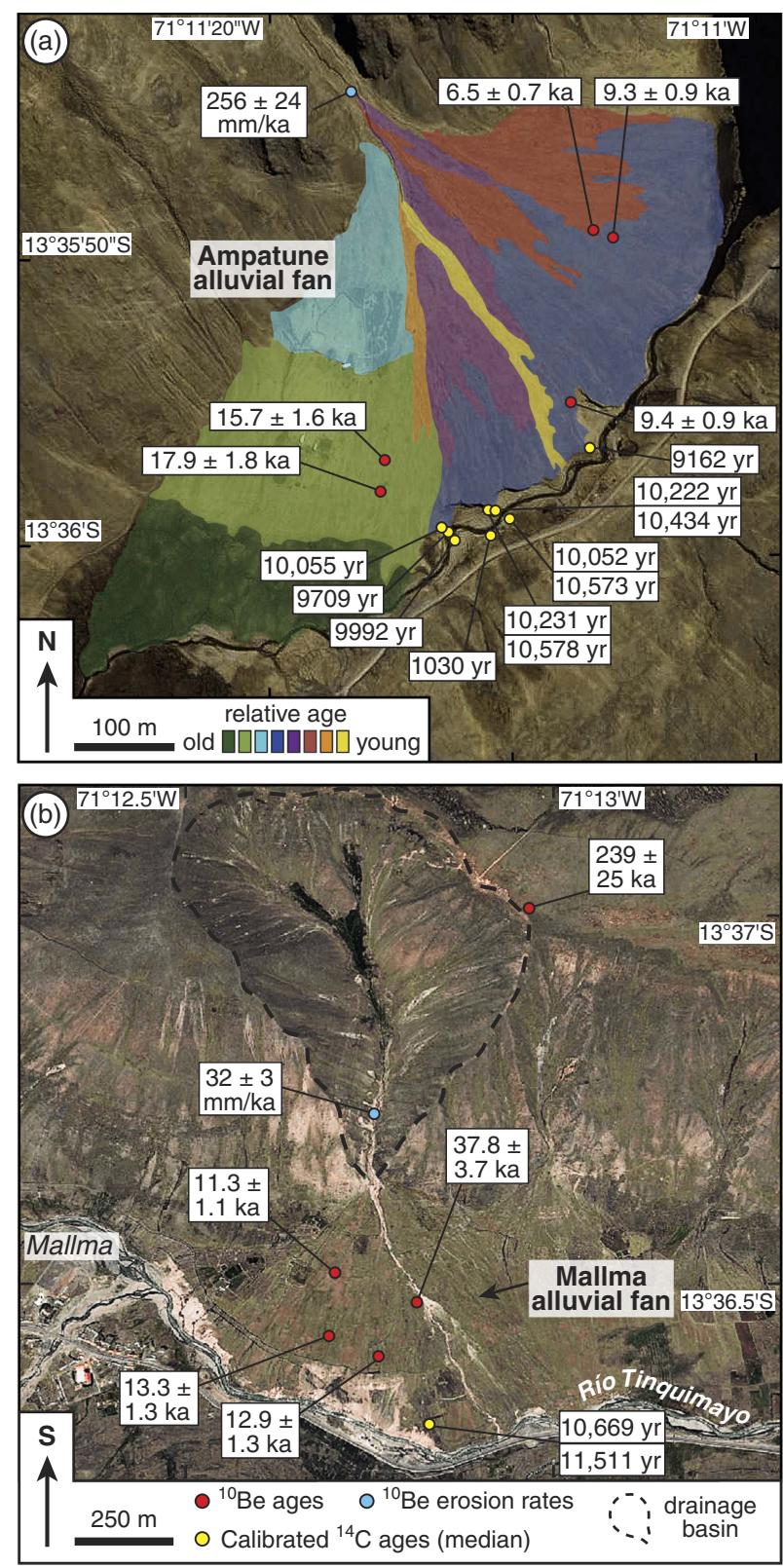

Figure 8. ${ }^{10} \mathrm{Be}$ exposure ages, ${ }^{10} \mathrm{Be}$ erosion rates, and calibrated ${ }^{14} \mathrm{C}$ ages obtained for the Ampatune (a) and Mallma (b) alluvial fans. ${ }^{10} \mathrm{Be}$ ages and erosion rates are shown with external errors. ${ }^{14} \mathrm{C}$ ages are given as calibrated median ages in years BP (for complete age ranges, see Table 3 ). In addition, coloured areas in panel (a) indicate the different lobes of the Ampatune fan and their relative ages based on the mapping of aerial photographs.

as for the deposition of the glaciofluvial sediments that occur in the upper parts of both catchments. From the stream sediment samples that we collected in the channels feeding the Ampatune and Mallma fans, we obtained spatially integrated catchment-wide erosion rates of $256 \pm 24 \mathrm{~mm} / \mathrm{ka}$ and $31.6 \pm 2.8 \mathrm{~mm} / \mathrm{ka}$, respectively (Table 2 , Fig. 8 ).

\section{Results from fan volume determination}

The fan volumes obtained from the reconstruction of the valley geometry underneath the two alluvial fans are $5.9 \times 10^{6} \mathrm{~m}^{3}$ for 
the Ampatune fan and $10.3 \times 10^{6} \mathrm{~m}^{3}$ for the Mallma fan, respectively. The uncertainty on these two values is estimated to be about $\pm 20 \%$ as shown by different runs of the interpolation, which results in absolute values and uncertainties of $5.9 \pm 1.2$ and $10.3 \pm 2.1 \times 10^{6} \mathrm{~m}^{3}$, respectively.

\section{DISCUSSION}

\section{Depositional history of the Ampatune and Mallma alluvial fans}

Our data set of ${ }^{10} \mathrm{Be}$ and ${ }^{14} \mathrm{C}$ ages allows deriving the postLGM depositional history of the two studied alluvial fans. While the ${ }^{10} \mathrm{Be}$ exposure ages constrain the deposition of the boulders on the fan surface, the radiocarbon dating provides minimum ages for the deposition of the underlying fan sediments (and maximum ages for the overlying sediments). In the following discussion, we use either the calibrated ${ }^{14} \mathrm{C}$ age range or simply the median ages (both are reported in Table 3). We also note that when comparing calibrated ${ }^{14} \mathrm{C}$ ages with ${ }^{10} \mathrm{Be}$ exposure ages it is necessary to consider the external uncertainties of the ${ }^{10} \mathrm{Be}$ ages, which include the systematic uncertainty of the ${ }^{10} \mathrm{Be}$ production rate. In contrast, internal uncertainties should be used when two (or more) ${ }^{10} \mathrm{Be}$ ages for one landform are compared with each other (e.g., Balco et al., 2008).

For the Ampatune fan, the two samples 15P6 and 15P7 from the second oldest fan lobe (light-green colour in Fig. 8a) have slightly different ${ }^{10} \mathrm{Be}$ ages of $15.7 \pm 0.6$ and $17.9 \pm 0.6 \mathrm{ka}$, respectively, when considering their internal uncertainties (Table 1). This age difference may be explained by a minor inherited ${ }^{10} \mathrm{Be}$ component in the older sample, which may have formed in the respective boulder before it was emplaced on the fan. If this interpretation is correct, it suggests that sediment deposition on the second oldest fan lobe came to an end at $15.7 \pm 1.6 \mathrm{ka}$ (external uncertainty). Subsequently, sedimentation shifted to the central part of the Ampatune fan (blue colour in Fig. 8a), where 9 out of 11 calibrated ${ }^{14} \mathrm{C}$ ages fall in the narrow range from 10,782 to $9541 \mathrm{cal} \mathrm{yr} \mathrm{BP}$ (Table 3). The fact that all sample pairs from different depths have stratigraphically consistent ${ }^{14} \mathrm{C}$ ages indicates the robustness of these age data. One slightly younger ${ }^{14} \mathrm{C}$ age of 9543-8607 cal yr BP agrees with the ${ }^{10} \mathrm{Be}$ ages of $9.4 \pm 0.9 \mathrm{ka}$ and $9.3 \pm 0.9$ ka obtained from the two boulders deposited on the same fan lobe (blue colour in Fig. 8a). Together, the ${ }^{14} \mathrm{C}$ and ${ }^{10} \mathrm{Be}$ ages document that the main volume of the Ampatune fan was deposited until $\sim 10 \mathrm{ka}$, although minor sedimentation continued for another few hundred years in the distal part of the fan. As the entire fan must have formed after the LGM (i.e., after $\sim 20 \mathrm{ka}$ ), our age data indicate a fast accumulation of fan deposits after the glaciers in the region retreated and the valleys became ice free. An initially rapid deposition of fan sediments is further supported by the blockage of the river directly upstream of the Ampatune fan and the formation of Laguna Ampatune (Fig. 4a). Since $\sim 10 \mathrm{ka}$, sediment delivery from the catchment of the Ampatune fan was restricted to the more proximal fan parts, as shown by one ${ }^{10} \mathrm{Be}$ age of $6.5 \pm 0.7 \mathrm{ka}$ for a rather young fan lobe (red colour in Fig. 8a).

The ${ }^{10} \mathrm{Be}$ and ${ }^{14} \mathrm{C}$ ages for the Mallma alluvial fan indicate a similar depositional history (Fig. 8b) as for the Ampatune fan. Two almost identical exposure ages of $13.3 \pm 0.5 \mathrm{ka}$ and $12.9 \pm 0.5 \mathrm{ka}$ (internal uncertainties), and a slightly younger age of $11.3 \pm 0.4 \mathrm{ka}$ (Table 1), indicate that deposition on the eastern part of the fan ceased between 13 and $11 \mathrm{ka}$. It is noteworthy that the youngest of the three ${ }^{10} \mathrm{Be}$ ages is from a boulder in the proximal part of the fan. Hence, as for the Ampatune fan the spatial distribution of these ages seems to indicate that deposition shifted from the relatively distal parts towards the apex of the Mallma fan. The two ${ }^{14} \mathrm{C}$ ages of $11,750-11,311$ and 10,770-10,566 cal yr BP (Table 3) indicate ongoing sediment deposition in this part of the Mallma fan at that time (Fig. 8b). As the respective samples were taken at a shallow depth of 0.8 and $1.0 \mathrm{~m}$ below the fan surface (Fig. 7b, Table 3), only a minor amount of sediment was deposited after $\sim 10.5 \mathrm{ka}$ in this distal portion of the fan. Any younger sediments must have been deposited in more proximal parts of the fan.

\section{Comparison between fan volumes and ${ }^{10} \mathrm{Be}$ erosion rates from fan catchments}

The catchment-wide ${ }^{10} \mathrm{Be}$ erosion rates obtained for the source areas of the Ampatune and Mallma fans are $256 \pm 24 \mathrm{~mm} / \mathrm{ka}$ and $31.6 \pm 2.8 \mathrm{~mm} / \mathrm{ka}$, respectively (Table 2). These rates fall within the wide range of catchment-wide erosion rates that were previously determined for catchments of different size in the Peruvian and Bolivian Andes (4-1350 mm/ka; e.g., Safran et al., 2005; Abbühl et al., 2010; Hippe et al., 2012; Carretier et al., 2015; Kober et al., 2015). Note that the calculation of such spatially integrated erosion rates assumes that (1) quartz is homogeneously distributed in the eroding rocks, (2) sediment in the stream channels is well mixed, (3) nuclide production is equal to nuclide outflux via erosion and radioactive decay, and (4) erosion is constant through time (e.g., Granger and Riebe, 2007; Reinhardt et al., 2007). In most settings these assumptions are unlikely to be fully met, which leads to an additional uncertainty of probably up to 20-30\% (Dunai, 2010).

In our study area, erosion has not been constant through time (as we will show subsequently). Furthermore, the presence of different lithologies-Pleistocene glaciofluvial sediments above the Palaeozoic bedrock-complicates the interpretation of the catchment-wide erosion rates, because their quartz content may differ (cf. Carretier et al., 2015). Hence, the uncertainties of the erosion rates are likely higher than $20-30 \%$; however, even for an uncertainty of $\sim 50 \%$, the two rates are still significantly different (i.e., $260 \pm 130 \mathrm{~mm} / \mathrm{ka}$ vs. $32 \pm 16 \mathrm{~mm} / \mathrm{ka}$ ). Given the similar size, relief, slope, and bedrock of both catchments, we consider the most likely explanation to be the weakly consolidated and easily erodible glaciofluvial sediments in the Ampatune catchment, where these sediments form debris-covered, actively eroding slopes (Fig. 3b). In contrast, the Pleistocene sediments in the Mallma catchment are coarser and much better consolidated (Fig. 3c). 
The time scale over which cosmogenic nuclide-based erosion rates integrate depends on the absolute value of the erosion rate. For the Ampatune catchment, this time scale is 2.5 $\mathrm{ka}$, whereas it is $\sim 20 \mathrm{ka}$ for the Mallma catchment (Table 2). By combining the erosion rates of $260 \pm 130$ and $32 \pm 16 \mathrm{~mm} /$ ka (again, we use a $50 \%$ uncertainty) with the volumes of the Ampatune and Mallma fans $\left(5.9 \pm 1.2 \times 10^{6}\right.$ and $10.3 \pm 2.1 \times$ $10^{6} \mathrm{~m}^{3}$, respectively) and their catchments areas (Ampatune: $0.20 \mathrm{~km}^{2}$; Mallma: $0.51 \mathrm{~km}^{2}$ ), we can estimate the time that would be needed to generate the sediment volume stored in the fans. This calculation, which assumes that erosion has been temporally constant, yields time periods of $100 \pm 50 \mathrm{ka}$ for the deposition of the Ampatune fan and $540 \pm 290 \mathrm{ka}$ for the Mallma fan (note that for converting eroded rock volumes into sediment volumes we used densities of 2.5 and $2.1 \mathrm{~g} / \mathrm{cm}^{3}$, respectively). As both fans were deposited after the LGM, these time periods exceed the true age of the fans by far, thus indicating that the rate of erosion must have varied considerably during the lifetime of the fans. When combined with the ${ }^{14} \mathrm{C}$ and ${ }^{10} \mathrm{Be}$ ages discussed previously, the discrepancy between the post-LGM fan ages and the long apparent time periods for fan deposition demonstrates that rates of catchment erosion and sediment delivery to both fans must have markedly declined through time.

To obtain a rough first-order estimate of the temporal variation of erosion, we use the ${ }^{10} \mathrm{Be}$ erosion rate for the Ampatune catchment, which integrates over the last $\sim 2.5 \mathrm{ka}$ (Table 2). Over this time interval, the assumption of a constant erosion rate can be regarded as reasonable. If we assume that the erosion rate of $\sim 260 \mathrm{~mm} / \mathrm{ka}$ is representative for the last $\sim 10$ ka (i.e., since the abrupt decline in sedimentation rate as shown by the ${ }^{10} \mathrm{Be}$ and ${ }^{14} \mathrm{C}$ ages), the average erosion rate in the Ampatune catchment between $\sim 20 \mathrm{ka}$ and $\sim 10 \mathrm{ka}$ can be determined. The average erosion-rate for this time interval is $\sim 2700 \mathrm{~mm} / \mathrm{ka}$ and about an order of magnitude higher than the Holocene rate measured with ${ }^{10} \mathrm{Be}$. These mean erosion-rate estimates for the late Pleistocene and Holocene are equivalent to sediment fluxes of $\sim 600 \mathrm{~m}^{3} / \mathrm{yr}$ and $\sim 60 \mathrm{~m}^{3} / \mathrm{yr}$, respectively.

For the Mallma catchment-fan system, the assumption of steady-state erosion over the integration time scale of $\sim 20 \mathrm{ka}$ cannot be valid, as indicated by the discrepancy between the post-LGM fan age and the apparent time of $\sim 540$ ka calculated for fan deposition. Thus, the ${ }^{10} \mathrm{Be}$-derived erosion rate of $\sim 32 \mathrm{~mm} / \mathrm{ka}$ is much too small to produce the sediment volume stored in the Mallma fan. One explanation for the low erosion rate of the catchment could be the admixture of longexposed material with high ${ }^{10} \mathrm{Be}$ concentrations from the edge of the high plateau above the catchment. Indeed, the quartzite boulder 15P8 near the upper catchment boundary has a ${ }^{10} \mathrm{Be}$ concentration more than ten times higher than the stream sediment sample $15 \mathrm{P} 13$ (i.e., $\sim 11.7 \times 10^{6}$ vs. $\sim 0.8 \times$ $10^{6} \mathrm{at} / \mathrm{g}$; Tables 1, 2). If we assume that-similar to the Ampatune fan- $90 \%$ of the sediments now stored in the Mallma fan have been eroded from the Mallma catchment between $\sim 20$ and $\sim 10 \mathrm{ka}$, the average erosion rate during this interval would be $\sim 1500 \mathrm{~mm} / \mathrm{ka}$ (equivalent to a sediment flux of $\sim 900 \mathrm{~m}^{3} / \mathrm{yr}$ ).
A decrease in the rate of erosion from the LGM to the Holocene has also been documented for unglaciated catchments in the Peruvian Andes. By comparing the ${ }^{10} \mathrm{Be}$ concentration of terrace fills and modern stream sediments, McPhillips et al. (2013) showed that the erosion of catchments with an area of several tens of square kilometres decreased from the late Pleistocene to the Holocene in response to a reduced precipitation. On a much larger scale, the relatively low ${ }^{10} \mathrm{Be}$ concentration of floodplain sediments in the Napo River basin east of the Andes appears to reflect a higher erosion rate in the upstream part of this catchment during the LGM as compared with the Holocene (Wittmann et al., 2011).

High rates of erosion, sediment flux, and fan deposition similar to the ones obtained from the studied fans in Peru were also reported from other regions that were glaciated during the last glacial period, for instance, for alluvial fans on Spitsbergen, Greenland, and in the European Alps (i.e., from regions that have also been glaciated during the last glacial period). On Spitsbergen, the time-averaged deposition rate for a fan with a similar size as the Ampatune and Mallma fans has been estimated at $580-720 \mathrm{~m}^{3} / \mathrm{yr}$ since fan buildup began 12.5-10 ka ago (Bernhardt et al., 2017). In contrast to the fans in Peru, the fan in Spitsbergen did not experience a significant decline in sediment deposition, because the deposition rate over the last $50 \mathrm{yr}$ of $\sim 480 \mathrm{~m}^{3} / \mathrm{yr}$ is only slightly lower than the long-term rate (Bernhardt et al., 2017). Similarly, aggradation of alluvial fans in the Zackenberg Valley in northeastern Greenland began in the early Holocene and continued throughout the different Holocene periods of warmer and cooler climate conditions at an average sedimentation rate of $450 \mathrm{~mm} / \mathrm{ka}$ (Cable et al., 2018). For a postglacial alluvial fan in the Swiss Alps, Hornung et al. (2010) estimated sediment volumes for different time periods in the early Holocene using a combination of ground penetrating radar survey and radiocarbon dating of palaeosols. Maximum sediment aggradation occurred during a cold climate interval between 7500 and 7000 cal yr BP corresponding to an erosion rate of $1070 \mathrm{~mm} / \mathrm{ka}$. In the Holocene climate optimum, sediment aggradation ceased despite higher humidity because of stabilization of slopes by vegetation. Erosion rates from late glacial valley fills of major Alpine valleys yield erosion rates between $\sim 1100$ and $\sim 2900 \mathrm{~mm} / \mathrm{ka}$ with an average of $\sim 1800 \mathrm{~mm} / \mathrm{ka}$ for the entire Alps (Hinderer, 2001). From the late glacial period to the Holocene, the sediment flux dropped by an order of magnitude (Hinderer, 2001), which matches well with the estimated drop of sediment flux in the studied fans in Peru.

\section{Correlation of fan sedimentation history with regional climate records}

In this section, we compare our results on the sedimentation history of the Ampatune and Mallma alluvial fans with data that record the late Quaternary climate evolution of the tropical Andes. The growth and shrinkage of glaciers and ice caps in 
that region has been constrained by dating moraines, kettle lakes, peat bogs, and in-place vegetation exposed by retreating glaciers (Mercer and Palacios, 1977; Goodman et al., 2001; Mark et al., 2002; Buffen et al., 2009; Kelly et al., 2012; Bromley et al., 2016). In addition, past changes in precipitation were inferred from biotic, chemical, and isotopic proxies in sediment cores from existing lakes and palaeolakes (Abott et al., 1997, 2000; Cross et al., 2000; Seltzer et al., 2000; Baker et al., 2001a, 2001b; Wolfe et al., 2001; Fritz et al., 2007). These lakesediment studies have been complemented by ${ }^{14} \mathrm{C}$ and U-Th dating of biogenic carbonate associated with palaeoshorelines in order to quantify absolute lake-level changes (Sylvestre et al., 1999; Placzek et al., 2006; Blard et al., 2011). In the following, we briefly describe the main environmental changes based on these studies and compare them with our results from the Ampatune and Mallma alluvial fans.

The maximum extent of glaciers and ice caps in the tropical Andes occurred about 22-20 ka ago and was broadly synchronous with the global LGM (Mark et al., 2002; Kelly et al., 2012; Bromley et al., 2016), even though the austral summer insolation reached a maximum at that time (Fig. 9a). During the LGM, the valleys in the Cordillera Vilcanota and the Qullqip'unqu mountains to the south and north of our study area, respectively (Fig. 2a), were occupied by glaciers (Goodman et al., 2001). In contrast, the palaeoplain above the Mallma catchment was not covered by ice during the last glaciation, as indicated by the minimum ${ }^{10} \mathrm{Be}$ age of $\sim 239 \mathrm{ka}$ (Fig. 8b, Table 1). Prior to $\sim 19 \mathrm{ka}$, the glaciers had already retreated from the Laguna Casercocha area to the east (see Fig. 2a; Goodman et al., 2001). It is not known when exactly the valleys in our study area became ice free, but the ${ }^{10} \mathrm{Be}$ age of $15.7 \pm 1.6 \mathrm{ka}$ for the second oldest lobe of the Ampatune fan (Fig. 8a) provides a minimum age constraint for the retreat of the glaciers from our study area (Fig. 2b, c).

During the culmination of the last glaciation, Lake Titicaca was a freshwater lake as indicated by the low abundance of benthic diatoms, the lack of $\mathrm{CaCO}_{3}$ in the lake sediments, and low $\delta^{13} \mathrm{C}$ values of total sedimentary organic carbon (Fig. 9b-d) (Baker et al., 2001b). At the same time, a shallow lake existed farther to the south in the Uyuni basin (Lake Sajsi cycle), which reached its highest level around $22 \mathrm{ka}$ (Fig. 9e) almost synchronously with the LGM (Placzek et al., 2006; Blard et al., 2011). Despite the existence of Lake Sajsi, a lacustrine record from a small lake in the Eastern Cordillera of Bolivia indicates that the moisture source from the Amazon basin was reduced during the LGM, thus suggesting relatively dry conditions (Mourguiart and Ledru, 2003). After the regression of Lake Sajsi, a major and rapid lake-level rise started at $\sim 18 \mathrm{ka}$ and culminated between 16.5 and $15 \mathrm{ka}$ (Lake Tauca cycle), when the lake level was $100 \mathrm{~m}$ higher than during the preceding Sajsi cycle (Fig. 9e) (Blard et al., 2011). The existence of Lake Tauca indicates a phase of high precipitation, which lasted for several millennia (e.g., Sylvestre et al., 1999; Baker et al., 2001b; Placzek et al., 2006; Blard et al., 2011) and occurred after glaciers had retreated from their maximum LGM extent (Goodman et al., 2001; Kelly et al., 2012; Bromley et al., 2016).

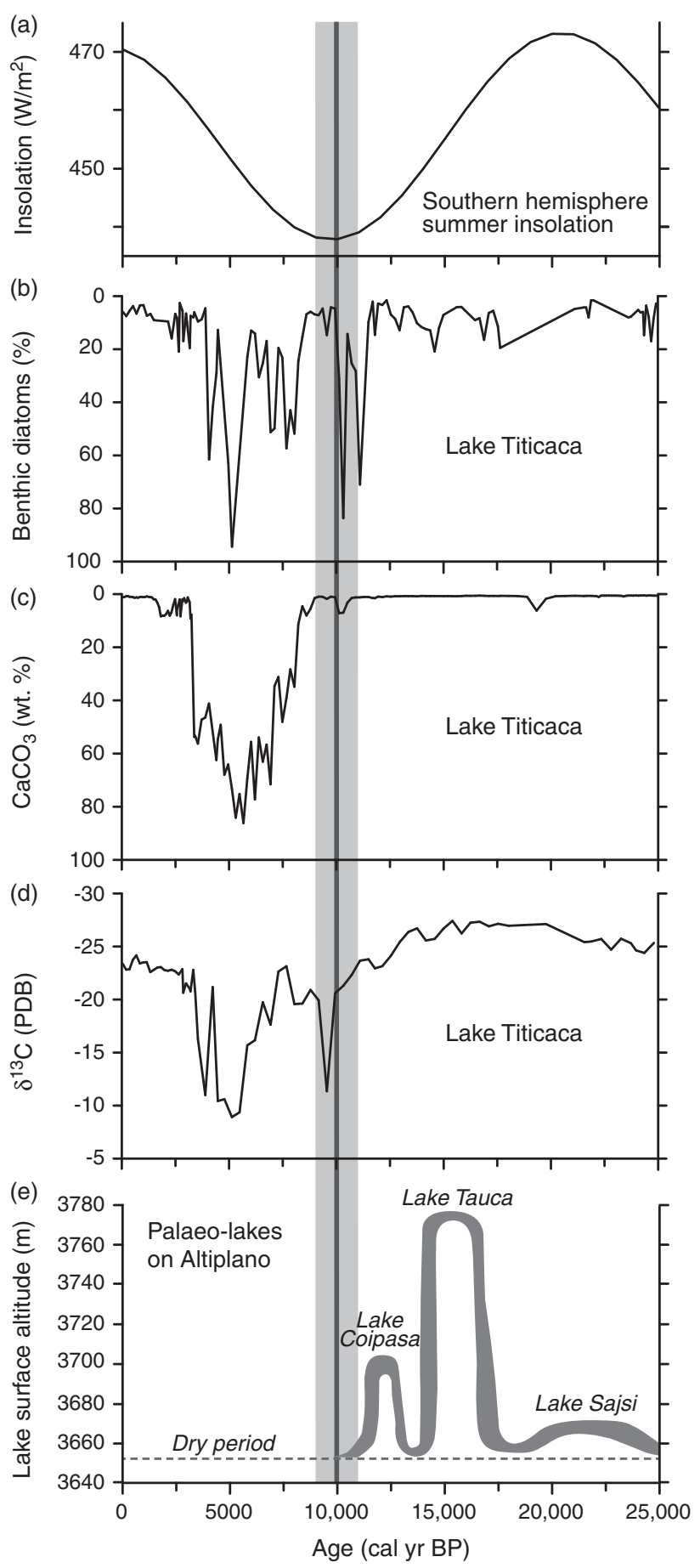

Figure 9. Proxies for climate evolution in the tropical Andes over the past $25,000 \mathrm{cal} \mathrm{yr} \mathrm{BP}$. The vertical grey band indicates the time when the sedimentation rate on the two studied alluvial fans decreased markedly. (a) Calculated January (austral summer) insolation at $15^{\circ} \mathrm{S}$ (Berger and Loutre, 1991). (b-d) Biotic, chemical, and isotopic data for sediment core 1PC from Lake Titicaca (modified from Baker et al., 2001b). Curves are all plotted such that up signifies higher lake levels. As the sedimentary organic matter is a mixture of planktonic algae with $\delta^{13} \mathrm{C}$ values of about $-25 \%$ and shallow-water macrophytes with $\delta^{13} \mathrm{C}$ values of about $-10 \%$, more negative $\delta^{13} \mathrm{C}$ values in panel (d) indicate a higher lake level. The isotopic composition of the sedimentary organic carbon is given relative to the Pee Dee belemnite (PDB) standard. (e) Lake-level curve for palaeolakes on the Altiplano (modified from Blard et al., 2011). 
We suggest that the rapid buildup of the Ampatune and Mallma fans occurred during the Lake Tauca wet period, which started at $\sim 18 \mathrm{ka}$ and ended about $14.5 \mathrm{ka}$ ago (Fig. 9e) (Blard et al., 2011). Higher rainfall (Sylvestre et al., 1999; Wolfe et al., 2001; Abott et al. 2003; Placzek et al., 2006; Blard et al., 2011) together with a widespread cover of hillslopes by unconsolidated, glacigenic deposits resulted in a climax of sediment supply. Apparently, the more humid conditions in our study area were not associated with an increase in stabilizing hillslope vegetation that would have been sufficient to inhibit erosion of the glacigenic deposits in the fan catchments. The occurrence of high sediment supply and fan formation during a humid period is in contrast to the widespread notion that sediment yield and hence fan aggradation rates typically increase during wet-dry transitions owing to a decrease in vegetation (e.g., Reheis et al., 1996; Miller et al., 2001; for a discussion see Dorn, 2009).

The Lake Tauca cycle was followed by a short phase with low lake levels and a drier climate, but lake levels were higher again from $\sim 13$ to $\sim 11.5 \mathrm{ka}$ (Lake Coipasa cycle; Fig. 9e) (Baker et al., 2001a; Plazcek et al., 2006; Blard et al., 2011). During this time interval, sedimentation on the Mallma fan came largely to an end as shown by three ${ }^{10} \mathrm{Be}$ exposure ages of $\sim 13.3$ to $\sim 11.3 \mathrm{ka}$ and two ${ }^{14} \mathrm{C}$ ages of $11,750-11,311$ and 10,770-10,566 cal yr BP (Fig. 8b; Tables 1, 3).

At $\sim 11,500$ cal yr BP, a large-amplitude drop in the level of Lake Titicaca commenced and lasted until about 10,000 cal yr BP (Baker et al., 2001b). This lake-level change is marked by the replacement of freshwater planktonic diatoms by benthic taxa and less negative $\delta^{13} \mathrm{C}$ values of the organic matter (Fig. 9b, d). In our study area, this drier period reduced the rate of sedimentation on the Ampatune fan and favoured the development of soil horizons, which yielded ${ }^{14} \mathrm{C}$ ages ranging from 10,782 to 9541 cal yr BP (Table 3). Minor sediment deposition on the fan continued between 10 and 9 ka and was roughly coeval with a short high stand of Lake Titicaca (Baker et al., 2001b). Subsequently, a much drier climate has persisted in the tropical Andes during most of the Holocene (e.g., Baker et al., 2001b; Wolfe et al., 2001; Placzek et al., 2006), and as a result no significant deposition on the studied alluvial fans has occurred since then.

\section{CONCLUSIONS}

The sedimentation history of two alluvial fans in the eastern Andes of Peru has been investigated with ${ }^{10} \mathrm{Be}$ exposure and ${ }^{14} \mathrm{C}$ dating in order to decipher how changes in climatic boundary conditions affect fan deposition and erosion in the source area. The new ${ }^{10} \mathrm{Be}$ exposure and ${ }^{14} \mathrm{C}$ ages are consistent for both fans and document intense erosion, fast sediment transport, and rapid deposition of alluvial sediments during two humid periods after the LGM. A shift to more arid conditions, which have prevailed through most of the Holocene after $\sim 9 \mathrm{ka}$, caused a marked drop in sediment deposition rates. We conclude that the classical concept of paraglacial sediment exhaustion of the middle latitudes may be strongly modified in the tropics by humidity shifts. Our study illustrates how ${ }^{10} \mathrm{Be}$ exposure dating of alluvial fan surfaces can be coupled with radiocarbon dating of fan interiors to reconstruct past changes in climate. Furthermore, our results highlight that erosion, sediment transport, and deposition in fan-catchment systems are strongly dependent on climate.

\section{ACKNOWLEDGMENTS}

We thank Anne Niehus (Universität Münster) for help in the lab during processing of the ${ }^{10} \mathrm{Be}$ samples and Veronika Rapelius (Universität Münster) for inductively coupled plasma-optical emission spectrometry (ICP-OES) analysis of quartz samples after etching. Rebecca Kämmerling, Vanessa Landscheidt, Anne Schnitzpahn, and Marek Naser contributed sediment logs, descriptions of sedimentary facies, and pebble petrology by their diploma theses. We thank Gudrun Drewes and Petra Posimowski from the Leibniz Institute for Applied Geophysics for radiocarbon sample preparation and measurements. ${ }^{14} \mathrm{C}$ ages from the Mallma fan were provided from Susanne Lindauer (Klaus-Tschira-Laboratory for Radiometric Dating Methods). Critical comments and suggestions by the editor (Derek Booth), the associate editor (Xiaoping Yang), and two anonymous reviewers helped us to improve the original version of this manuscript. The Generic Mapping Tools (GMT) by Wessel and Smith (1998) were used to create Figure 1. Funding for this study was provided by the Leibniz Universität Hannover (startup funds to A. Hampel).

\section{SUPPLEMENTARY MATERIAL}

To view supplementary material for this article, please visit https://doi.org/10.1017/qua.2018.106

\section{REFERENCES}

Abbott, M.B., Seltzer, G.O., Kelts, K.R., Southon, J., 1997. Holocene paleohydrology of the tropical Andes from lake records. Quaternary Research 47, 70-80.

Abbott, M.B., Wolfe, B.B., Aravena, R., Wolfe, A.P., Seltzer, G.O., 2000. Holocene hydrological reconstructions from stable isotopes and paleolimnology, Cordillera Real, Bolivia. Quaternary Science Reviews 19, 1801-1820.

Abbott, M.B., Wolfe, B.B., Wolfe, A.P., Seltzer, G.O., Aravena, R., Mark, B.G., Polissar, P.J., Rodbell, D. T., Rowe, H.D., Vuille, M., 2003. Holocene paleohydrology and glacial history of the central Andes using multiproxy lake sediment studies. Palaeogeography, Palaeoclimatology, Palaeoecology 194, 123-138.

Abbühl, L.M., Norton, K.P., Schlunegger, F., Kracht, O., Aldahan, A., Possnert, G., 2010. El Niño forcing on ${ }^{10}$ Be-based surface denudation rates in the northwestern Peruvian Andes? Geomorphology 123, 257-268.

Audebaud, E., Vargas, L.V., 1998. Mapa geologico del cuadrangulo de Ocongate, escala 1:100 000. Servicio de Geologia y Mineria, Departamente del Cuzco, Ministerio de Energia y Minas. Cusco, Peru.

Baker, P.A., Rigsby, C.A., Seltzer, G.O., Fritz, S.C., Lowenstein, T. K., Bacher, N.P., Veliz, C., 2001a. Tropical climate changes at 
millennial and orbital timescales on the Bolivian Altiplano. Nature 409, 698-701.

Baker, P.A., Seltzer, G.O., Fritz, S.C., Dunbar, R.B., Grove, M.J., Tapia, P.M., Cross, S.L., Rowe, H.D., Broda, J.P., 2001b. The history of South American tropical precipitation for the past 25,000 years. Science 291, 640-643.

Balco, G., Stone, J.O., Lifton, N.A., Dunai, T.J., 2008. A complete and easily accessible means of calculating surface exposure ages or erosion rates from ${ }^{10} \mathrm{Be}$ and ${ }^{26} \mathrm{Al}$ measurements. Quaternary Geochronology 3, 174-195.

Bellier, O., Bourlès, D.L., Beaudouin, T., Braucher, R., 1999. Cosmic Ray Exposure (CRE) dating in a wet tropical domain: late Quaternary fan emplacements in central Sulawesi (Indonesia). Terra Nova 11, 174-180.

Berger, A., Loutre, M.F., 1991. Insolation values for the climate of the last 10 million years. Quaternary Science Reviews 10, 297-317.

Bernhardt, H., Reiss, D., Hiesinger, H., Hauber, E., Johnsson, A., 2017. Debris flow recurrence periods and multi-temporal observations of colluvial fan evolution in central Spitsbergen (Svalbard). Geomorphology 296, 132-141.

Blair, T.C., 1999. Sedimentology of the debris-flow-dominated Warm Spring Canyon alluvial fan, Death Valley, California. Sedimentology 46, 941-965.

Blair, T.C., McPherson, J.G., 1994. Alluvial fan processes and forms. In: Abrahams, A.D., Parsons, A.J. (Eds.), Geomorphology of Desert Environments. CRC Press, Boca Raton, FL, pp. 354-402.

Blair, T.C., McPherson, J.G., 1998. Recent debris-flow processes and resultant form and facies of the Dolomite alluvial fan, Owens Valley, California. Journal of Sedimentary Research 68, 800-818.

Blair, T.C., McPherson, J.G., 2009. Processes and forms of alluvial fans. In: Parsons, A.J., Abrahams, A.D. (Eds.), Geomorphology of Desert Environments. 2nd ed. CRC Press, Boca Raton, FL, pp. 413-467.

Blard, P.-H., Sylvestre, F., Tripati, A.K., Claude, C., Causse, C., Coudrain, A., Condom, T., et al., 2011. Lake highstands on the Altiplano (Tropical Andes) contemporaneous with Heinrich 1 and the Younger Dryas: new insights from ${ }^{14} \mathrm{C}, \mathrm{U}-\mathrm{Th}$ dating and $\delta^{18} \mathrm{O}$ of carbonates. Quaternary Science Reviews 30, 3973-3989.

Borchers, B., Marrero, S., Balco, G., Caffee, M., Goehring, B., Lifton, N., Nishiizumi, K., Phillips, F., Schaefer, J., Stone, J., 2016. Geological calibration of spallation production rates in the CRONUS-Earth project. Quaternary Geochronology 31, 188-198.

Bromley, G.R.M., Schäfer, J.M., Hall, B.L., Rademaker, K.M., Putnam, A.E., Todd, C.E., Hegland, M., Winckler, G., Jackson, M.S., Strand, P.D., 2016. A cosmogenic ${ }^{10}$ Be chronology for the local last glacial maximum and termination in the Cordillera Oriental, southern Peruvian Andes: implications for the tropical role in global climate. Quaternary Science Reviews 148, 54-67.

Bronk Ramsey, C., 2009. Bayesian analysis of radiocarbon dates. Radiocarbon 51, 337-360.

Buffen, A.M., Thompson, L.G., Mosley-Thompson, E., Huh, K.I., 2009. Recently exposed vegetation reveals Holocene changes in the extent of the Quelccaya Ice Cap, Peru. Quaternary Research $72,157-163$.

Bull, W.B., 1962. Relations of alluvial fan size and slope to drainage basin size and lithology in western Fresno County, California. US Geological Survey Professional Paper 450-B, 51-53.

Bull, W.B., 1964. Geomorphology of segmented alluvial fans in western Fresno County, California. US Geological Survey Professional Paper 352-E, 89-129.
Bull, W.B., 1977. The alluvial-fan environment. Progress in Physical Geography 1, 222-270.

Bull, W.B., 1991. Geomorphic Responses to Climatic Change. Oxford University Press, New York.

Cable, S., Christiansen, H.H., Westergaard-Nielsen, A., Kroon, A., Elberling, B., 2018. Geomorphological and cryostratigraphical analyses of the Zackenberg Valley, NE Greenland and significance of Holocene alluvial fans. Geomorphology 303, 504-523.

Cabrera, J., Sébrier, M., Mercier, J.L., 1991. Plio-Quaternary geodynamic evolution of a segment of the Peruvian Andean Cordillera located above the change in the subduction geometry: the Cuzco region. Tectonophysics 190, 331-362.

Carretier, S., Regard, V., Vassallo, R., Martinod, J., Christophoul, F., Gayer, E., Audin, L., Lagane, C., 2015. A note on ${ }^{10} \mathrm{Be}-$ derived mean erosion rates in catchments with heterogeneous lithology: examples from the western Central Andes. Earth Surface Processes and Landforms 40, 1719-1729.

Cesta, J.M., Ward, D.J., 2016. Timing and nature of alluvial fan development along the Chajnantor Plateau, northern Chile. Geomorphology 273, 412-427.

Chiverrell, R., Jakob, M., 2013. Radiocarbon dating: alluvial fan/ debris cone evolution and hazards. In: Schneuwly-Bollschweiler, M., Stoffel, M., Rudolf-Miklau, F. (Eds.), Dating Torrential Processes on Fans and Cones. Advances in Global Change Research 47, 265-282.

Chmeleff, J., von Blanckenburg, F., Kossert, K., Jakob, D., 2010. Determination of the ${ }^{10} \mathrm{Be}$ half-life by multicollector ICP-MS and liquid scintillation counting. Nuclear Instruments and Methods in Physics Research Section B: Beam Interactions with Materials and Atoms 268, 192-199.

Church, M., Ryder, J.M., 1972. Paraglacial sedimentation: a consideration of fluvial processes conditioned by glaciation. Geological Society of America Bulletin 83, 3059-3072.

Cross, S.L., Baker, P.A., Seltzer, G.O., Fritz, S.C., Dunbar, R.B., 2000. A new estimate of the Holocene lowstand level of Lake Titicaca, central Andes, and implications for tropical palaeohydrology. Holocene 10, 21-32.

Dade, W.B., Friend, P.F., 1998. Grain-size, sediment-transport regime, and channel slope in alluvial rivers. Journal of Geology 106, 661-676.

Densmore, A.L., Allen, P.A., Simpson, G., 2007. Development and response of a coupled catchment fan system under changing tectonic and climatic forcing. Journal of Geophysical Research 112, F01002.

Dewald, A., Heinze, S., Jolie, J., Zilges, A., Dunai, T., Rethemeyer, J., Melles, M., et al., 2013. CologneAMS, a dedicated center for accelerator mass spectrometry in Germany. Nuclear Instruments and Methods in Physics Research Section B: Beam Interactions with Materials and Atoms 294, 18-23.

Dorn, R.I., 2009. The role of climatic change in alluvial fan development. In: Parsons, A.J., Abrahams, A.D. (Eds.), Geomorphology of Desert Environments. Springer, New York, pp. 723-742.

Dorsey, R.J., Umhoefer, P.J., Falk, P.D., 1997. Earthquake clustering inferred from Pliocene Gilbert-type fan deltas in the Loreto basin, Baja California Sur, Mexico. Geology 25, 679-682.

Dühnforth, M., Densmore, A.L., Ivy-Ochs, S., Allen, P.A., Kubik, P.W., 2007. Timing and patterns of debris flow deposition on Shepherd and Symmes creek fans, Owens Valley, California, deduced from cosmogenic ${ }^{10} \mathrm{Be}$. Journal of Geophysical Research 112, F03S15. 
Dühnforth, M., Densmore, A.L., Ivy-Ochs, S., Allen, P.A., Kubik, P.W., 2017. Early to Late Pleistocene history of debris-flow fan evolution in western Death Valley (California) using cosmogenic ${ }^{10} \mathrm{Be}$ and ${ }^{26} \mathrm{Al}$. Geomorphology 281, 53-65.

Dunai, T.J., 2010. Cosmogenic Nuclides: Principles, Concepts and Applications in the Earth Surface Sciences. Cambridge University Press, Cambridge.

Ehlers, J., Gibbard, P.L., 2004. Quaternary Glaciations - Extent and Chronology. Part III: South America, Asia, Africa, Australasia, Antarctica. Developments in Quaternary Science 2. Elsevier, Amsterdam.

Ehlers, J., Gibbard, P.L., Hughes, P.D., 2011. Introduction. In.: Ehlers, J., Gibbard, P.L., Hughes, P.D. (Eds.), Quaternary Glaciations - Extent and Chronology: A Closer Look. Developments in Quaternary Sciences, Vol. 15. Elsevier, Amsterdam, pp. $1-14$.

Franke, D., Hornung, J., Hinderer, M., 2014. A combined study of radar facies, lithofacies and three-dimensional architecture of an alpine alluvial fan (Illgraben fan, Switzerland). Sedimentology, 62, 57-86.

Fritz, S.C., Baker, P.A., Seltzer, G.O., Ballantyne, A., Tapia, P., Cheng, H., Edwards, R.L., 2007. Quaternary glaciation and hydrologic variation in the South American tropics as reconstructed from the Lake Titicaca drilling project. Quaternary Research 68, 410-420.

Geyh, M.A., 1990. ${ }^{14} \mathrm{C}$ dating of loess. Quaternary International $7 /$ 8, 115-118.

Geyh, M.A., 2005. ${ }^{14} \mathrm{C}$ dating - still a challenge for users? Zeitschrift für Geomorphologie Supplement 139, 63-86.

Gibling, M.R., 2006. Width and thickness of fluvial channel bodies and valley fills in the geological record: A literature compilation and classification. Journal of Sedimentary Research 76, 731-770.

Goethals, M.M., Hetzel, R., Niedermann, S., Wittmann, H., Fenton, C.R., Kubik, P.W., Christl, M., von Blanckenburg, F., 2009. An improved experimental determination of cosmogenic ${ }^{10} \mathrm{Be} /{ }^{21} \mathrm{Ne}$ and ${ }^{26} \mathrm{Al} /{ }^{21} \mathrm{Ne}$ production ratios in quartz. Earth and Planetary Science Letters 284, 187-198.

Goodman, A.Y., Rodbell, D.T., Seltzer, G.O., Mark, B.G., 2001. Subdivision of glacial deposits in southeastern Peru based on pedogenic development and radiometric ages. Quaternary Research 56, 31-50.

Granger, D.E., Riebe, C.S., 2007. Cosmogenic nuclides in weathering and erosion. In: Holland, H.D., Turekian, K.K. (Eds.), Surface and Ground Water, Weathering, and Soils. Treatise of Geochemistry 5, 1-43.

Harvey, A.M., Mather, A.E., Stokes, M., 2005. Alluvial fans: geomorphology, sedimentology, dynamics-introduction. A review of alluvial-fan research. Geological Society London Special Publications 251, 1-7.

Harvey, A.M., Wigand, P.E., Wells, S.G., 1999. Response of alluvial fan systems to the late Pleistocene to Holocene climatic transition: contrasts between the margins of pluvial Lakes Lahontan and Mojave, Nevada and California, USA. Catena 36, 255-281.

Hinderer, M., 2001. Late Quaternary denudation of the Alps, valley and lake fillings and modern river loads. Geodinamica Acta 14, 231-263.

Hippe, K., Kober, F., Zeilinger, G., Ivy-Ochs, S., Maden, C., Wacker, L., Kubik, P.W., Wieler, R., 2012. Quantifying denudation rates and sediment storage on the eastern Altiplano, Bolivia, using cosmogenic ${ }^{10} \mathrm{Be},{ }^{26} \mathrm{Al}$, and in situ ${ }^{14} \mathrm{C}$. Geomorphology 179, 58-70.
Hogg, A.G., Hua, Q., Blackwell, P.G., Niu, M., Buck, C.E., Guilderson, T.P., Heaton, T.J., et al., 2013. SHCal13 Southern Hemisphere calibration, 0-50,000 years cal BP. Radiocarbon 55, 1889-1903.

Hornung, J., Pflanz, D., Hechler, A., Beer, A., Hinderer, M., Maisch, M., Bieg, U., 2010. 3-D architecture, depositional patterns and climate triggered sediment fluxes of an alpine alluvial fan (Samedan, Switzerland). Geomorphology 115, 202-214.

Humphrey, N.F., Heller, P.L., 1995. Natural oscillations in coupled geomorphic systems: an alternative origin for cyclic sedimentation. Geology 23, 499-502.

Ivy-Ochs, S., Dühnforth, M., Densmore, A.L., Alfimov, V., 2013. Dating fan deposits with cosmogenic nuclides. In: SchneuwlyBollschweiler, M., Stoffel, M., Rudolf-Miklau, F. (Eds.), Dating Torrential Processes on Fans and Cones. Advances in Global Change Research 47, 243-263.

Jennings, K.L., Bierman, P.R., Southon, J., 2003. Timing and style of deposition on humid-temperate fans, Vermont, United States. Geological Society of America Bulletin 115, 182-199.

Kelly, M.A., Lowell, T.V., Applegate, P.J., Smith, C.A., Phillips, F. M., Hudson, A.M., 2012. Late glacial fluctuations of Quelccaya Ice Cap, southeastern Peru. Geology 40, 991-994.

Kober, F., Zeilinger, G., Hippe, K., Marc, O., Lendzioch, T., Grischott, R., Christl, M., Kubik, P.W., Zola, R., 2015. Tectonic and lithological controls on denudation rates in the central Bolivian Andes. Tectonophysics 657, 230-244.

Kohl, C.P., Nishiizumi, K., 1992. Chemical isolation of quartz for measurement of in-situ-produced cosmogenic nuclides. Geochimica et Cosmochimica Acta 56, 3583-3587.

Korschinek, G., Bergmaier, A., Faestermann, T., Gerstmann, U.C., Knie, K., Rugel, G., Wallner, A., et al., 2010. A new value for the half-life of ${ }^{10} \mathrm{Be}$ by heavy-ion elastic recoil detection and liquid scintillation counting. Nuclear Instruments and Methods in Physics Research Section B: Beam Interactions with Materials and Atoms 268, 187-191.

La Frenierre, J., Huh, K.I., Mark, B.G., 2011. Ecuador, Peru and Bolivia. In: Ehlers, J., Gibbard, P.L., Hughes, P.D. (Eds.), Quaternary Glaciations - Extent and Chronology: A Closer Look. Developments in Quaternary Sciences, Vol. 15. Elsevier, Amsterdam, 773-802.

Lal, D., 1991. Cosmic ray labeling of erosion surfaces: in situ nuclide production rates and erosion models. Earth and Planetary Science Letters 104, 424-439.

Lang, A., 2013. Luminescence dating of alluvial fans and cones. In: Schneuwly-Bollschweiler, M., Stoffel, M., Rudolf-Miklau, F. (Eds.), Dating Torrential Processes on Fans and Cones. Advances in Global Change Research 47, 283-295.

Mark, B.G., Seltzer, G.O., Rodbell, D.T., Goodman, A.Y., 2002. Rates of deglaciation during the last glaciation and Holocene in the Cordillera Vilcanota-Quelccaya Ice Cap region, southeastern Peru. Quaternary Research 57, 287-298.

McPhillips, D., Bierman, P.R., Crocker, T., Rood, D.H., 2013. Landscape response to Pleistocene-Holocene precipitation change in the Western Cordillera, Peru: ${ }^{10} \mathrm{Be}$ concentrations in modern sediments and terrace fills. Journal of Geophysical Research: Earth Surface 118, 2488-2499.

Meinsen, J., Winsemann, J., Roskosch, J., Brandes, C., Frechen, M., Dultz, S., Böttcher, J., 2014. Climate control on the evolution of Late Pleistocene alluvial-fan and aeolian sand-sheet systems in NW Germany. Boreas 43, 42-66.

Mercer, J.H., Palacios, M.O., 1977. Radiocarbon dating of the last glaciation in Peru. Geology 5, 600-604. 
Miall, A.D., 1996. The Geology of Fluvial Deposits: Sedimentary Facies, Basin Analysis and Petroleum Geology. Springer, Berlin.

Miller, J., Germanoski, D., Waltman, K., Tausch, R., Chambers, J., 2001. Influence of late Holocene hillslope processes and landforms on modern channel dynamics in upland watersheds of central Nevada. Geomorphology 38, 373-391.

Mourguiart, P., Corrège, T., Wirrmann, D., Argollo, J., Montenegro, M.E., Pourchet, M., Carbonel, P., 1998. Holocene palaeohydrology of Lake Titicaca estimated from an ostracod-based transfer function. Palaeogeography, Palaeoclimatology, Palaeoecology 143, 51-72.

Mourguiart, P., Ledru, M.-P., 2003. Last Glacial Maximum in an Andean cloud forest environment (Eastern Cordillera, Bolivia). Geology 31, 195-198.

Nichols, G., 2009. Sedimentology and Stratigraphy. 2nd ed. Wiley \& Sons, West Sussex, UK.

Nishiizumi, K., Imamura, M., Caffee, M.W., Southon, J.R., Finkel, R. C., McAninch, J., 2007. Absolute calibration of ${ }^{10} \mathrm{Be}$ AMS standards. Nuclear Instruments and Methods in Physics Research Section B: Beam Interactions with Materials and Atoms 258, 403413.

Oguchi, T., Ohmori, H., 1994. Analysis of relationships among alluvial fan area, source basin area, basin slope, and sediment yield. Zeitschrift für Geomorphologie 38, 405-420.

Paola, C., Heller, P.L., Angevine, C.L., 1992. The large-scale dynamics of grain-size variation in alluvial basins, 1: theory. Basin Research 4, 73-90.

Placzek, C., Quade, J., Patchett, P.J., 2006. Geochronology and stratigraphy of late Pleistocene lake cycles on the southern Bolivian Altiplano: implications for causes of tropical climate change. Geological Society of America Bulletin 118, 515-532.

Regmi, N.R., McDonald, E.V., Bacon, S.N., 2014. Mapping Quaternary alluvial fans in the southwestern United States based on multiparameter surface roughness of lidar topographic data. Journal of Geophysical Research 119, 12-27.

Reheis, M.C., Slate, J.L., Throckmorton, C.K., McGeehin, J.P., SarnaWojcicki, A.M., Dengler, L., 1996. Late Quaternary sedimentation on the Leidy Creek fan, Nevada-California: geomorphic responses to climate change. Basin Research 8, 279-299.

Reinhardt, L.J., Hoey, T.B., Barrows, T.T., Dempster, T.J., Bishop, P., Fifield, L.K., 2007. Interpreting erosion rates from cosmogenic radionuclide concentrations measured in rapidly eroding terrain. Earth Surface Processes and Landforms 32, 390-406.

Rodbell, D.T., Seltzer, G.O., Mark, B.G., Smith, J.A., Abbott, M.B., 2008. Clastic sediment flux to tropical Andean lakes: records of glaciation and soil erosion. Quaternary Science Reviews 27, 1612-1626.

Roskosch, J., Tsukamoto, S., Meinsen, J., Frechen, M., Winsemann, J., 2012. Luminescence dating of an Upper Pleistocene alluvial fan and aeolian sandsheet complex: the Senne in the Münsterland
Embayment, NW Germany. Quaternary Geochronology 10, 94-101.

Safran, E.B., Bierman, P.R., Aalto, R., Dunne, T., Whipple, K.X., Caffee, M., 2005. Erosion rates driven by channel network incision in the Bolivian Andes. Earth Surface Processes and Landforms 30, 1007-1024.

Saito, K., Oguchi, T., 2005. Slope of alluvial fans in humid regions of Japan, Taiwan and the Philippines. Geomorphology 70, 147-162.

Sanchez, A.F., Zapata, A.M., 2002. Mapa geologico del cuadrangulo de Ocongate revisado y actualisado, escala 1: 100000 Instituto Geologico Minero y Metalurgico (Ingemmet), Lima, Peru.

Schürch, P., Densmore, A.L., Ivy-Ochs, S., Rosser, N.J., Kober, F., Schlunegger, F., McArdell, B., Alfimov, V., 2016. Quantitative reconstruction of late Holocene surface evolution on an alpine debris-flow fan. Geomorphology 275, 46-57.

Seltzer, G., Rodbell, D., Burns, S., 2000. Isotopic evidence for late Quaternary climatic change in tropical South America. Geology 28, 35-38.

Servicio Nacional de Meteorología e Hidrología del Perú. Mapa Climático del Perú (accessed April 6, 2017). http://www.senamhi. gob.pe/?p=mapa-climatico-del-peru.

Spiske, M., Reimann, C., Bahlburg, H., Carlotto, V., 2006. Sedimentology and facies analysis of the Ordovician San José and Sandia formations in the Sandia region, eastern Cordillera of southern Peru. Boletin de la Sociedad Geologica del Peru 101, 121-138.

Stone, J.O., 2000. Air pressure and cosmogenic isotope production. Journal of Geophysical Research 105, 23753-23759.

Stuiver, M., Polach, H.A., 1977. Discussion: reporting of ${ }^{14} \mathrm{C}$ data. Radiocarbon 19, 355-363.

Sylvestre, F., Servant, M., Servant-Vildary, S., Causse, C., Fournier, M., Ybert, J.-P., 1999. Lake-level chronology on the southern Bolivian Altiplano $\left(18^{\circ}-23^{\circ} \mathrm{S}\right)$ during late-glacial time and the early Holocene. Quaternary Research 51, 54-66.

Ventra, D., Nichols, G.J., 2014. Autogenic dynamics of alluvial fans in endorheic basins: outcrop examples and stratigraphic significance. Sedimentology 61, 767-791.

Wessel, P., Smith, W.H.F., 1998. New, improved version of Generic Mapping Tools released. Eos 79, 579.

Wittmann, H., von Blanckenburg, F., Guyot, J.L., Laraque, A., Bernal, C., Kubik, P.W., 2011. Sediment production and transport from in situ-produced cosmogenic ${ }^{10} \mathrm{Be}$ and river loads in the Napo River basin, an upper Amazon tributary of Ecuador and Peru. Journal of South American Earth Sciences 31, 45-53.

Wolfe, B.B., Aravena, R., Abbott, M.B., Seltzer, G.O., Gibson, J.J., 2001. Reconstruction of paleohydrology and paleohumidity from oxygen isotope records in the Bolivian Andes. Palaeogeography, Palaeoclimatology, Palaeoecology 176, 177-192. 